\title{
The potential of genetically enhanced plants to address food insecurity
}

\author{
Paul Christou ${ }^{1 *}$ and Richard M. Twyman ${ }^{2}$ \\ ${ }^{1}$ Fraunhofer Institute for Molecular Biology and Applied Ecology (IME), Grafschaft, Auf dem Aberg 1, 57392 \\ Schmallenberg, Germany \\ ${ }^{2}$ Department of Biology, University of York, Heslington, York YO10 5HD, UK
}

\begin{abstract}
Food insecurity is one of the most important social issues faced today, with 840 million individuals enduring chronic hunger and three billion individuals suffering from nutrient deficiencies. Most of these individuals are poverty stricken and live in developing countries. Strategies to address food insecurity must aim to increase agricultural productivity in the developing world in order to tackle poverty, and must provide long-term improvements in crop yields to keep up with demand as the world's population grows. Genetically enhanced plants provide one route to sustainable higher yields, either by increasing the intrinsic yield capability of crop plants or by protecting them from biotic and abiotic constraints. The present paper discusses a range of transgenic approaches that could increase agricultural productivity if applied on a large scale, including the introduction of genes that confer resistance to pests and diseases, or tolerance of harsh environments, and genes that help to lift the intrinsic yield capacity by increasing metabolic flux towards storage carbohydrates, proteins and oils. The paper also explores how the nutritional value of plants can be improved by genetic engineering. Transgenic plants, as a component of integrated strategies to relieve poverty and deliver sustainable agriculture to subsistence farmers in developing countries, could have a significant impact on food security now and in the future.
\end{abstract}

Food insecurity: Genetically enhanced plants: Developing countries

\section{Introduction}

In an ideal world, everyone would have secure access to an adequate supply of safe and nutritious food. This is something that Western societies take for granted, given the seemingly unlimited quantity and variety of fresh produce available on supermarket shelves. In the developing world, however, 840 million individuals are chronically undernourished, surviving on fewer than $8000 \mathrm{~kJ}(2000 \mathrm{kcal}) / \mathrm{d}$ (Pinstrup-Andersen et al. 1999; Food and Agriculture Organization, 2001). Many more individuals, perhaps one half of the world's population in total, suffer from diseases caused by dietary deficiencies and inadequate supplies of vitamins and minerals (Graham et al. 2001).

Despite the prevalence of hunger and malnutrition, global food production has outpaced population growth over the last 40 years thanks mainly to the successes of the Green Revolution (Pachico et al. 2000). Today's food insecurity is caused not by insufficient food production, but by poverty, with nearly 1.3 billion individuals living on less than US $\$ 1 / \mathrm{d}$ and another 2 billion only marginally better off (Smith et al. 2000; World Bank, 2000). These, the world's most deprived and impoverished individuals, do not have secure access to food. Most of the poor are rural farmers in developing countries, depending entirely on small-scale agriculture for their own subsistence and to make their livings. Because of limited purchasing power, the poorest farmers generally cannot irrigate their crops nor buy herbicides and pesticides. This leads to soil exhaustion and falling yields, and leaves the crops susceptible to pests, diseases and natural disasters such as drought. Many farmers are eventually forced to abandon their land and move to cities, adding to the growing problem of urban poverty and hunger (Royal Society of London et al. 2000; Smith et al. 2000; Department for International Development, 2002).

Any long-term strategy to address food insecurity in the developing world must tackle the underlying problem of poverty by increasing the level of rural employment-based income through increased agricultural productivity (Lipton, 1999; Persley, 2000; Smith et al. 2000). It must also take population growth into account. The world's population is predicted to double over the next 40 years, with over $95 \%$

\footnotetext{
Abbreviations: ACC, 1-aminocyclopropane-1-carboxylate; Bt, Bacillus thuringiensis; Cry, crystal; GA, gibberellic acid; GNA, Galanthus nivalis agglutinin; PEPC, phosphoenolpyruvate carboxylase; PR-proteins, pathogenesis-related proteins; RYMV, rice yellow mottle virus.

* Corresponding author: Professor P. Christou, fax +49 2972 302328, email cristou@ime.fraunhofer.de
} 
of individuals being born in developing countries (Byrnes $\&$ Bumb, 1998). Therefore, food production must increase by at least $40 \%$ to feed all the extra mouths, while land and water resources dwindle due to increased urbanisation, industrialisation and pollution (Byerlee et al. 2000; Rosegrant et al. 2001). The only solution to this problem is to increase the yields of major food crops, particularly cereal grains, using currently available land and less water. This will need to be achieved with a variety of approaches, including the efficient use of organic and inorganic fertilisers, irrigation strategies, soil and water conservation, pest and disease management and the production of improved plant varieties with higher yields.

It is envisaged that crop varieties with improved agronomic performance will be generated using a number of methods, some based on conventional breeding, others on more recent developments in biotechnology, and perhaps some by combining both conventional and molecular strategies (Huang et al. 2002a). The use of transgenic plants offers the greatest promise for the rapid integration of improved varieties into traditional cropping systems because improved plant lines can be generated quickly and with relative precision once suitable genes for transfer have been identified. It is recognised that biotechnology is not a magic wand that can free the world from poverty, hunger and malnutrition. However, we support the view that the use of transgenic plants, as one component of a wider strategy including conventional breeding and other forms of agricultural research, can contribute in a substantial manner towards the achievement of food security now and in the future. Significant challenges remain, not only in the achievement of the necessary scientific breakthroughs, but also in ensuring technology transfer to locally adapted crops and the negotiation of intellectual and technological property rights that protect inventors without encumbering the subsistence farmers for whom the improved crops are intended. The remainder of the present review is divided into four sections that explore different transgenic strategies that can be used to improve agricultural productivity; either by reducing extrinsic constraints or by increasing the intrinsic yield potential of crops. These approaches are shown schematically in Fig. 1.

\section{Genetic modification targets I: pest and disease resistance}

Pests and pathogens are collectively described as biotic stresses and can be defined as biological constraints that reduce yields either by adversely affecting plant growth and development, or by consuming and/or spoiling the products of food crops in the field or in storage. In terms of food production, the most significant biotic constraints include insect pests, weeds, viral diseases, microbial diseases and nematodes. Together, these factors are thought to reduce crop yields worldwide by up to $30 \%$, but in developing countries this value may be much higher because the climatic conditions favour the survival and breeding of insect pests, which not only feed on plants but also act as vectors for many viral diseases. Weeds and insect pests have been identified as primary targets for GM technology, with the vast majority of commercially grown transgenic plants modified for herbicide tolerance, insect resistance or both (James, 2002).

The development of these GM crops has focused on the needs of producers in industrialised countries, since this offers the best opportunity for biotechnology companies to recoup the costs of their investments. Therefore, while there have been large cost savings and moderate yield increases in large mechanised farms practising intensive agriculture, there has been relatively little impact in the developing world. More than 40 million ha of land are planted with GM crops in the industrialised nations, compared with just 13 million ha in developing countries. In both cases, the majority of the land is devoted to Roundup Ready soyabeans (resistant to the herbicide glyphosate) and pest-resistant cotton and yellow maize varieties expressing toxin genes from the bacterium Bacillus thuringiensis $(B t)$.

In order to address food insecurity issues in developing countries, the focus of biotechnology is beginning to turn away from temperate region cash crops, towards staple food crops favoured by rural farmers, where the increases in agricultural productivity and sustainability are required the most. China is leading the way with several new GM varieties of rice, wheat, maize and potato approaching commercialisation, modified for resistance to insect pests and a range of economically important viral and microbial diseases. Importantly, these products have been developed by public research institutions therefore limiting the constraints imposed by intellectual property issues and overburdening (and at times irrational) regulation (Huang et al. $2002 a, b)$. At the time of writing, field trials with pest- or disease-resistant transgenic crops are being conducted by public research institutions in eleven developing countries, with the ultimate aim of delivering new crop varieties to subsistence farmers with the least purchasing power (Toenniessen et al. 2003). About twenty-five different crops are under evaluation, including tropical crops such as cassava, sweet potato and groundnut that are important sources of food in the developing world but which have been largely ignored by the private research companies in the West.

In this section, the different ways in which GM technology is being used to produce pest- and pathogen-resistant crops for developing country agriculture are explored, focusing on a small number of well-characterised pests and diseases. Importantly, transgenic plants have the potential to overcome many of the disadvantages of conventional breeding because there are no species barriers, so genes conferring resistance can be imported from any source and can be modified to improve their performance before they are introduced into the plant genome. The process is also much quicker than traditional plant breeding. Once a suitable resistance gene has been identified, resistant plant lines can be produced rapidly. Furthermore, transgenic methodology allows the development and implementation of strategies to accumulate resistance genes active against different pests and pathogens in the same plant line (resistance gene stacking) either by crossing singly resistant plants or by introducing multiple genes simultaneously. The same strategy can be used to limit the probability of pests and pathogens adapting to overcome the resistance, since multiple resistance proteins targeting the same organism can also 


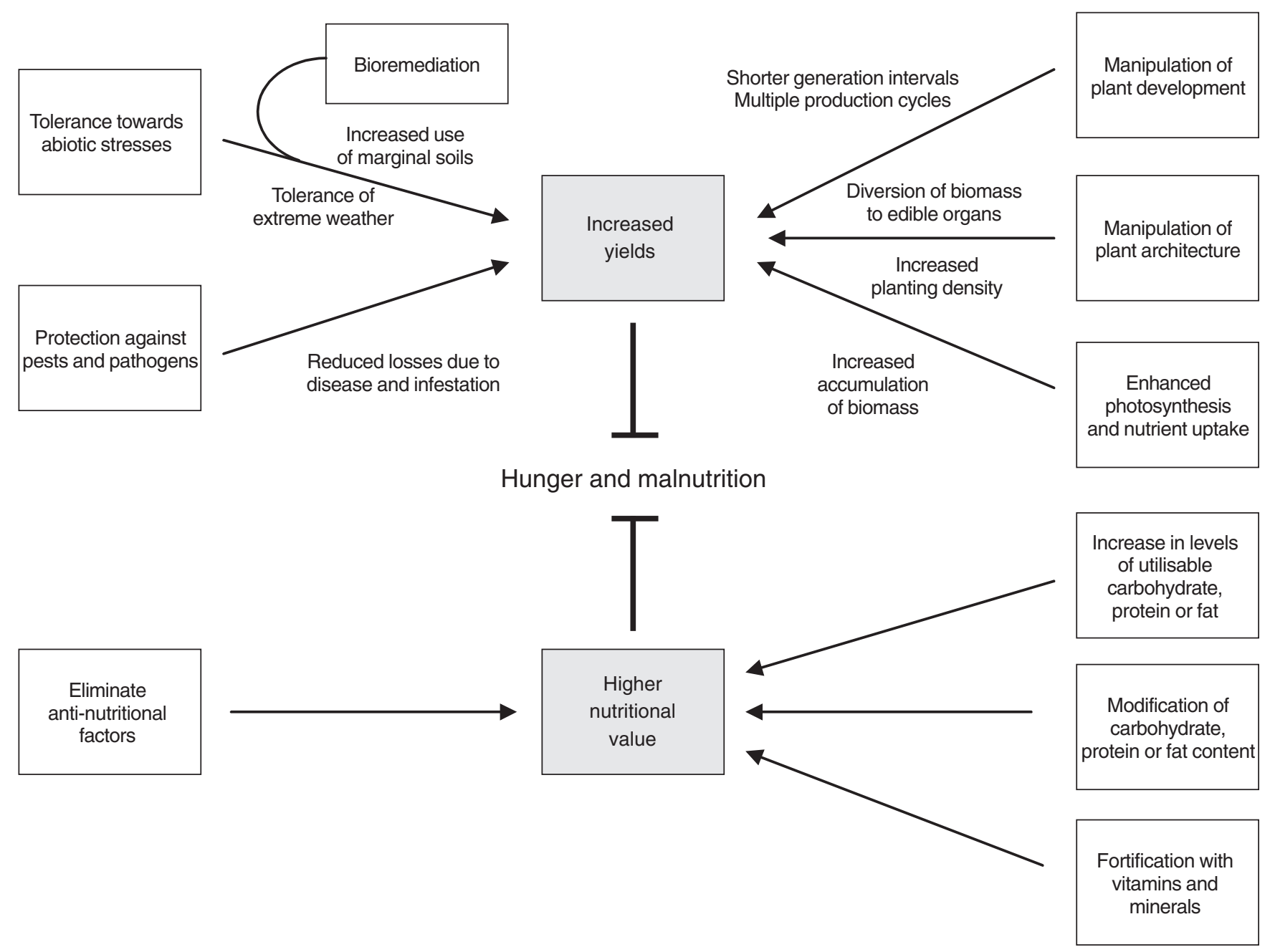

Fig. 1. Transgenic strategies to tackle hunger and malnutrition. Strategies on the left help to eliminate constraints and thus realise the yield or nutritional potential of the crop. Strategies on the right help to raise the yield ceiling by releasing unlocked potential.

be stacked in the plants, a strategy defined as resistance pyramiding.

\section{Specific targets: weeds}

Weeds compete with crops for resources, in some cases by parasitism. The cost of weeds, measured in terms of reduced yields, the application of herbicides, and the mechanical and manual labour required to control them, is probably the largest single input into agriculture. For this reason, weed control has been identified as the primary target for first generation GM technology and most of the transgenic plants grown in the world today have been modified for herbicide tolerance, allowing the use of safe, broad-spectrum herbicides such as glyphosate and basta. Although herbicide resistance is the most common strategy for weed control, several others are being evaluated including enhanced allelopathy, in which crop plants are modified to produce their own weed-inhibiting compounds (for a review, see Duke et al. 2002). Typically, the primary crop is the target of modification, but such approaches can also be used to produce aggressive 'cover crops' that inhibit weeds before the primary crop is planted. There has been recent interest in the use of suicide transgenes inducible by temperature or photoperiod cues to cause cover crops to selfdestruct at the correct time of year (Stanilaus \& Cheng, 2002). It is also possible to modify microbial pathogens so that they preferentially attack weeds (for example, see Amsellum et al. 2002).

Because GM technology in the West is driven predominantly by the potential for commercial gain, research has focused on the weed problems facing farmers in the industrialised nations. There has been little interest in developing crops with resistance to the weed species that plague subsistence crops in the developing world, even though this would have an immediate impact on food security. For 
example, Striga is a genus of parasitic flowering plants that infests cereal and legume crops throughout Africa. It is particularly difficult to control in maize crops and causes yield losses estimated at US\$7 billion annually (Berner et al. 1995). Genes allowing the selective control of this weed by herbicide application have been identified (Joel et al. 1995) but thus far no transgenic varieties have been produced (Gressel, 2002). Progress towards the selective control of Striga in Africa has been made solely through mutation and conventional breeding for imazapyr resistance in maize (Kanampiu et al. 2001, 2002).

\section{Specific targets: insect pests}

Many crop plants are also food for insect pests, and devastating losses occur throughout the world due to pest infestations either in the field or in stored products such as cereal and legume grains. In the developing world, about one half of all crop production is thought to be lost to insects, $15 \%$ of these losses occurring due to post-harvest consumption and spoilage (Gatehouse et al. 1993). Insects not only cause direct yield losses by damaging and consuming plants, they also act as vectors for many viral diseases and the damage they inflict encourages microbial infections.

In the industrialised world, pest control is heavily dependent on chemical inputs, which are expensive and damaging to the environment. The chemicals are non-selective, killing harmless and beneficial insects as well as pests, and accumulating in water and soil. In the developing world, many farmers are too poor to afford pesticides and are left at the mercy of nature. In any case, chemical control measures are ineffective against some of the worst pests, such as the rice brown planthopper (Nilaparvata lugens) which feeds by sucking sap from the phloem. Another major problem is that insects evolve resistance to chemical insecticides (Schuler et al. 1998).

Because of these difficulties, insect pests represent another primary target of GM technology (Estruch et al. 1997; Schuler et al. 1998). The genetic modification of plants to express insect-resistance genes offers the potential to overcome all of the shortcomings listed above, since genes that show exquisite specificity towards particular pest species have been isolated from bacteria and other sources, thus minimising the threat towards non-target organisms. Furthermore, the expression of such proteins within plants allows the effective control of insects that feed or shelter within the plant, and the degree of protection is not influenced by the weather, as is the case for topical chemical pesticide applications. Finally, the probability of insects becoming resistant to the transgenic plants can be reduced by a number of strategies, such as pyramiding resistance genes affecting different receptors in the target insect, conditional expression and the provision of 'safe-havens' or refuges, to reduce selection pressure. Several different types of genes have been exploited to control insect pests, including bacterial toxins, protease inhibitors and lectins.

Bacillus thuringiensis genes. Although several microbial species have been used as sources of insecticidal genes, the most popular source by far is Bt (Peferoen, 1997; de Maagd et al. 1999). This is a spore-forming bacterium that produces insecticidal toxins during the sporulation process. The toxins are alternatively known as crystal (Cry) proteins, $\delta$-endotoxins or $B t$ toxins. They are expressed as inert protoxins that are activated by proteinases in the highly alkaline environment of the insect gut. This provides an important safety barrier since the environment in which the toxins are activated is unique to insects, and thus it is safe for other animals, and humans, to ingest plants expressing $B t$ toxins. Once activated, the toxins interact with receptors on the midgut epithelium cells creating pores in the plasma membrane by disrupting osmotic balance. This results in paralysis and the ultimate death of the insect.

Nearly $40 \%$ of all the commercially grown transgenic plants in the world contain synthetic insecticidal toxin genes from Bt (James, 2002). Different subspecies and strains of bacteria produce toxins with different, but always highly specific, host-ranges allowing individual pests to be targeted (van Frankenhuyzen \& Nystrom, 2002). Over thirty plant species have been engineered with modified $B t$ genes and many of these have been commercialised or are undergoing field trials (for reviews, see Schuler et al. 1998; de Maagd et al. 1999; Hilder \& Boulter, 1999; Llewellyn \& Higgins, 2002). Therefore, a large amount of quantitative data has been obtained in terms of improved yields and reduced insecticide use. For example, the NewLeaf $\AA$ potato variety marketed by Monsanto contains a modified cry $3 \mathrm{~A}$ toxin gene. It demonstrated very effective control of the Colorado potato beetle and allowed a $40 \%$ reduction in pesticide applications (Carpenter \& Gianessi, 2001). In the case of YieldGuard $\AA$ maize, there has been effective control of the target pest (the European corn borer; Ostrinia nubilalis) but only a small reduction in pesticide use $(1.5 \%)$ reflecting the fact that pesticides are ineffective against this species and are rarely used (Carpenter \& Gianessi, 2001). An important knock-on effect of the $B t$ maize variety was the reduction in insect-mediated feeding damage, which helped to limit adventitious access and further spoilage by fungal pathogens and mycotoxin contamination (Llewellyn \& Higgins, 2002).

In the developing world, $B t$ cotton varieties are leading the way in the fight against hunger by showing how GM technology can increase agricultural yields and contribute to the alleviation of poverty. $B t$ cotton was adopted by China in 1997 and now accounts for about one-third of all cotton grown in that country (Pray et al. 2002). Rural farmers have reported yield gains year on year (5-10\%) and a reduction in labour and agrochemical costs. $B t$ cotton varieties are now grown commercially in six developing countries (China, India, Argentina, Indonesia, Mexico and South Africa), with particularly encouraging results in Mexico where these varieties have all but eliminated infestation problems on smallholder farms caused by the pink bollworm (Pectinophora gossypiella; Traxler et al. 2003).

The provision of locally adapted $B t$ cereal crops would have a more direct impact on hunger in the developing world, and this is beginning to happen in the case of $B t$ maize, which is grown in both Argentina and South Africa by smallholders for commercial exploitation and their own consumption. Bt maize varieties are nearing approval in 
China, and are being field-tested in Egypt, the Philippines and Kenya. While in some countries the technology has been developed by the US company Monsanto and adapted for local varieties by backcrossing, $B t$ maize in China and Kenya has been developed by scientists working in public research institutions (Bohorova et al. 2001; Huang et al. $2002 b)$.

Insect-resistant $B t$ rice containing the $c r y l A b$ gene was first produced over 10 years ago (Fujimoto et al. 1993). The transgenic plants were resistant against lepidopteran pests such as the striped stem borer (Chilo suppressalis), which showed mortality rates of 10-50\% compared with no mortality in the untransformed control plants. Several groups have reported enhanced resistance to the striped stem borer and yellow stem borer (Scirpophaga incertulas) in rice plants transformed with crylAb (Wunn et al. 1996; Ghareyazie et al. 1997; Wu et al. 1997; Alam et al. 1998; Datta et al. 1998). Mortality rates of up to $100 \%$ have also been reported with rice plants expressing crylAc (Nayak et al. 1997) and cry2A (Bano-Maqbool et al. 1998). Bt rice is now being field-tested in several developing countries and is reaching the last stages of the approval process in China (Tu et al. 2000; Ye et al. 2001a; Khanna \& Raina, 2002). The field evaluations in China have been very successful. Tu et al. (2000) showed that a $B t$ commercial hybrid variety expressing the crylAb gene produced a $28 \%$ yield increase compared with wild-type plants. Ye et al. (2001a) produced a rice line expressing $c r y l A b$ that was entirely protected against stem borer attack throughout the growing season, while more than $80 \%$ of untransformed plants were damaged. Similarly, the crylAc transgenic IR-64 and PusaBasmati 1 lines produced by Khanna \& Raina (2002) were almost completely protected against the yellow stem borer.

Recent developments include the stacking of multiple $B t$ genes and the use of fusion genes to provide enhanced resistance against a range of insect pests. For example, Cheng et al. (1998) produced rice plants expressing both $c r y l A b$ and $c r y l A c$, which were shown to eliminate stem borer larvae within $5 \mathrm{~d}$. Ye et al. (2001b) described transgenic plants expressing a cry $1 A b / c r y l A c$ fusion gene, and showed that damage from four lepidopteran pests was almost completely eliminated. In an adjacent plot, nontransgenic plants were protected from attack by lepidopteran insects by pesticide application, but instead succumbed to planthoppers, which are homopteran (sapsucking) pests. This direct reduction in pest damage, plus the secondary reductions in insecticide-induced planthopper infestation and insect-transmitted viral diseases, has great potential to increase yields and contribute significantly to food security throughout Asia.

Protease and amylase inhibitors. While bacterial toxins have been widely used as insecticides, there is also increasing research into the use of enzymes that inhibit the digestion of food in the insect gut and therefore act as anti-feedants. Many plants appear to express such enzymes as a defensive strategy and the genetic manipulation of crops now allows the corresponding genes to be transferred between species. Depending on whether the dietary intake of the insect is predominantly protein or carbohydrate, the expression of proteinase inhibitors (Lawrence \& Koundal,
2002) and $\alpha$-amylase inhibitors (Chrispeels et al. 1998) should prevent the uptake of nutrients and therefore starve or delay the development of insect larvae. Insects that predominantly consume plant proteins produce gut proteases such as trypsin and elastase, which are required for digestion. Many plants express trypsin inhibitors, particularly in their seeds, and these can be manipulated to protect susceptible plants from insect pests. In China, a GM rice variety resistant to three rice pests is coming to the end of its environmental release trials and will probably be commercialised in the near future. This variety contains a $B t$ gene, the gene for cowpea trypsin inhibitor and the $\mathrm{Xa21}$ gene for resistance against bacterial blight (see later; p. 28).

Lectins. The $B t$ toxins and digestion inhibitors discussed earlier (pp. 26-28) are active mainly against lepidopteran and coleopteran species. There are few insecticidal proteins that are active against the significant threat of homopteran (sap-sucking) pests, such as the rice brown planthopper, which not only destroy plants directly but act as vectors for a number of very severe viral diseases (for example, rice tungro virus, grassy stunt virus and ragged stunt virus). One group of proteins that does possess such activity is the lectins, with snowdrop lectin (Galanthus nivalis agglutinin; GNA) the most widely exploited because it has been shown to have no toxic effect on mammals (Gatehouse \& Gatehouse, 1998). Importantly, several groups have shown that the gna gene can be stacked with $B t$ toxin genes to provide simultaneous resistance to a broad range of insect pests. For example, Bano-Maqbool et al. (2001) have produced transgenic rice plants expressing two $B t$ genes and gna, and these plants show resistance to the three most important rice pests in Asia: rice leaf folder, yellow stem borer and brown planthopper.

\section{Specific targets: crop diseases}

Many plants have evolved resistance mechanisms that protect them either generally from pathogens or against particular pathogen species. The transfer of genes from resistant to susceptible species is one GM strategy that can be used to accelerate conventional breeding for disease resistance (Salmeron \& Vernooij, 1998; Stuiver \& Custers, 2001).

The plant cell has a number of general defence responses that occur in the presence of any pathogen. One of the first responses is a burst of reactive oxygen species, resulting in the activation of signal transduction pathways that lead to programmed cell death (Lamb \& Dixon, 1997). This is known as the hypersensitive response and prevents the spread of infection by killing cells at the infection site. Metabolic changes in adjacent tissues then occur to generate physical and chemical barriers to further infection. The cell wall is strengthened, antimicrobial molecules called phytoallexins are synthesised, defence peptides such as defensins and thionins are expressed and there may also be synthesis of pathogenesis-related proteins (PR-proteins) such as hydrolytic enzymes that break down bacterial and fungal cell walls (Bowles, 1990; Kuc, 1995). Plant cells surrounding the infection site also produce long-range signals that induce the synthesis of PR-proteins throughout the plant. This is known as systemic-acquired resistance and 
protects the plant from subsequent attacks by the same pathogen and others (Sticher et al. 1997).

As well as these general responses, plants may synthesise specific resistance proteins that interact with particular components of a given pathogen. These components are known as avirulence factors, and they are neutralised by contact with the resistance proteins (Flor, 1971; Bent, 1996).

In addition to exploiting natural plant defences, foreign genes can be expressed in plants to prevent or delay pathogen infections. Two major strategies are utilised: pathogen-derived resistance, in which a pathogen gene is expressed in the protected plant, and pathogen-targeted resistance, in which a foreign gene is used to interfere with pathogen infection or reproduction. Examples of all these defence strategies are discussed below.

Enhancing general defence responses to prevent fungal diseases. Pathogenic fungi are responsible for a large number of crop diseases that are very difficult to control using conventional chemical measures (Punja, 2001). As well as reducing yields, fungi also produce mycotoxins that contaminate stored grain and pose a severe threat to human health (Scholthof, 2003). Major fungi that infect food crops include Rhizoctonia spp. (affecting many crops and causing diseases such as sheath blight in rice), Fusarium spp. (which cause scab in wheat and barley), Puccinia spp. (which cause rust diseases in wheat), Erysiphe graminis $\mathrm{f}$. sp. tritici (which causes powdery mildew in wheat), Mycosphaerella fijiensis (which causes black Sigatoka disease in banana) and Magnaporthae grisea (which causes blast in rice). Perhaps the best-known fungal disease of plants is late blight of potato, caused by Phytophthera infestans, which was responsible for the Irish potato famine in the 1840s and has re-emerged recently as a new and more aggressive disease of potato and tomato that is resistant to fungicides such as metalaxyl (Fry \& Goodwin, 1997).

Most plants engineered for fungal resistance express proteins that are toxic to pathogenic fungi or inhibit their growth. Over twenty plant species, including many commercially important crops, have been transformed with genes encoding chitinases or glucanases (Punja, 2001). These are PR-proteins, released by the host plant in response to pathogen attack, which hydrolyse the major components of the fungal cell wall. Their expression is therefore designed to inhibit hyphal growth. In most cases, disease progress has been arrested but the overall level of control is only moderate. Tobacco, carrot and tomato have each been engineered to express both chitinase and glucanase simultaneously, and these plants show greater resistance, indicating that the two enzymes can work synergistically (van den Elzen et al. 1993; Zhu et al. 1994; Jongedijk et al. 1995).

Chitinases and glucanases are not the only PR-proteins to exhibit anti-fungal activity and others have been expressed in transgenic plants with encouraging results. Proteins of the PR-5 group (osmotitin and thaumatin) inhibit fungal growth by causing the formation of pores in the plasma membrane. Such proteins have been expressed in tobacco, rice, wheat, potato and carrot. In most cases they have reduced lesion development and delayed the onset of disease against various fungal pathogens (Liu et al. 1994; Zhu et al. 1996; Chen et al. 1999; Datta et al. 1999). Anti-fungal proteins of the PR-1a and PR-10 groups have also been used successfully (for example, Chang et al. 1993; Wang et al. 1999).

Small peptides with anti-fungal activity, for example, defensins and thionins, have been shown to confer resistance to pathogens when expressed in transgenic plants (Cary et al. 2000; Osusky et al. 2000; Li et al. 2001). Potatoes expressing lucerne defensin have been shown to be resistant to Verticillium infection in field trials (Gao et al. 2000) and hevein-like proteins expressed in tomato conferred resistance to Phytophtora capsici and Fusarium oxysporum (Lee et al. 2003).

An alternative to the expression of proteins that kill or restrict fungal pathogens is the expression of proteins that block the activity of fungal virulence products and therefore prevent infection. The first barrier to an invading pathogen is generally the plant cell wall and infection is initiated by the secretion of enzymes, such as polygalacturonidase, that weaken the wall and allow it to be breached. Powell et al. (2000) have produced transgenic tomato plants expressing pear polygalacturonase-inhibiting protein; infection by Botrytis cinevea was shown to be inhibited. Fungi also secrete toxins such as oxalic acid as part of their pathogenic arsenal. Transgenic tomato plants expressing Collybia oxalate decarboxylase, which breaks down and neutralises the toxin, demonstrated enhanced resistance against another commercially important pathogen, Sclerotinia sclerotiorum (Kesarwani et al. 2000). Finally, genes can be introduced into the plant that increase the production of toxic secondary metabolites, such as phytoallexins. For example, the grape stilbene synthase (resveratrol synthase) gene, which has been expressed in tobacco, tomato, barley, rice and wheat, has been shown to confer resistance to a range of fungal pathogens (Hain et al. 1993; Stark-Lorenzen et al. 1997; Thomzik et al. 1997; Leckband \& Lörz, 1998; Fettig \& Hess, 1999).

A specific resistance gene providing resistance against bacterial blight. Bacterial diseases cause significant losses in crop yields, and many different transgenic strategies have been developed to prevent infection or reduce the severity of symptoms (Herrera-Estrella \& Simpson, 1995; Mourgues et al. 1998; Punja, 2001). One of the most prevalent bacterial diseases of rice is bacterial blight, which causes losses totalling over US \$250 million every year in Asia alone. This disease has received a great deal of attention due to the discovery of a resistance gene complex in the related wild species Oryza longistaminata. The trait was introgressed into cultivated rice line IR-24 and was shown to confer resistance to all known isolates of the blight pathogen Xanthomonas oryzae pv. oryzae in India and the Philippines (Khush et al. 1990).

Further investigation of the resistance complex resulted in the isolation of a gene, named $X a 21$, encoding a receptor tyrosine kinase (Song et al. 1995). The transfer of this gene to susceptible rice varieties resulted in plant lines showing strong resistance to a range of isolates of the pathogen (Wang et al. 1996; Tu et al. 1998; Zhang et al. 1998). As 
stated earlier (p. 27), the $X a 21$ gene has been stacked with two genes for insect resistance to generate a rice line with resistance to bacterial blight and a range of insect pests, and this is due for commercial release in China in the near future (Huang et al. 2002a). As with insect resistance genes, the widespread use of transgenic plants carrying a single resistance factor could prompt the evolution of new pathogen strains with counteradaptive properties. Therefore, other blight resistance transgenes are being tested for possible deployment either alone or in combination with Xa21. For example, Tang et al. (2001) have produced rice plants expressing a ferredoxin-like protein that had previously been shown to delay the hypersensitive response to the pathogen Pseudomonas syringae pv. syringae. In inoculation tests with $X$. oryzae pv. oryzae, all the transgenic plants showed enhanced resistance against the pathogen.

Pathogen-derived resistance against viral diseases. Pathogen-derived resistance to viruses can be achieved in a number of different ways, but the most widely used strategy is the expression of transgenes encoding viral coat proteins, which appear to block viral replication at both the RNA and protein levels. Several examples of this strategy have been demonstrated in rice, which is host to ten or more disease-causing viruses. In South-East Asia, for example, tungro is the most damaging disease. This is caused by the combined action of two viruses: rice tungro bacilliform virus and rice tungro spherical virus. In Central and South America, rice hoja blanca virus has been known to cause up to $100 \%$ losses. Pathogen-derived resistance to these diseases has been achieved in experimental plants by expressing coat-protein genes from rice tungro bacilliform virus, rice tungro spherical virus and rice hoja blanca virus (Kloti et al. 1996; Lentini et al. 1996; Sivamani et al. 1999).

In Africa, the major cause of disease in lowland rice ecosystems is rice yellow mottle virus (RYMV), which caused a yield loss of 330000 tonnes between 1998 and 2000. The only naturally occurring resistance genes to RYMV are found in African landraces, which are difficult to cross with the cultivated varieties. Therefore, transgenes were constructed from the RNA polymerase gene of RYMV, which encodes a highly conserved component of the virus replicative machinery (Pinto et al. 1999). The gene was transferred to three West African cultivated rice varieties that are grown in regions with the worst records of viral disease and where the yield gaps were the highest. All three varieties were shown to be resistant to RYMV, and one of the varieties was resistant to isolates of the virus from several different locations in Africa. In the best-performing lines, viral replication was completely blocked over several generations. The resistance appeared to be RNA-mediated.

Pathogen-targeted resistance against viral diseases. Several classes of non-viral gene products can be used to provide specific protection against viral pathogens, including ribosome-inactivating proteins, which block protein synthesis (Moon et al. 1997; Tumer et al. 1997), ribonucleases, which destroy the virus genome (Watanabe et al.
1995), 2',5'oligoadenylate synthetases, which interfere with replication (Ogawa et al. 1996), ribozymes, which cleave viral genomes causing them to be degraded by cellular enzymes (de Feyter et al. 1996; Kwon et al. 1997) and recombinant antibodies, which bind and neutralise viral epitopes (Tavladoraki et al. 1993; Schillberg et al. 2001). Thus far, none of these strategies has been tested in field trials so their overall impact is uncertain.

Pathogen-targeted resistance against nematodes. Nematodes are pathogens that parasitise plant roots. While many spend their entire life cycle in the rhizosphere, others, particularly of the genera Meloidogyne, Globodera and Heterodera, invade the root and alter plant gene expression to establish specialised feeding structures. As well as changing root morphology, this drain on resources results in poor growth and wilting and facilitates the transmission of plant viruses (Jung et al. 1998).

Nematodes represent a significant threat to food security in Africa, Asia and South America. In some parts of Asia, Meloidogyne species (root knot nematodes) can reduce rice yields by up to $70 \%$. In Africa, Meloidogyne and Pratylenchus species cause 20-40 \% losses in upland rice systems and in banana plantations. The impact of nematodes on food security is best exemplified in Bolivia, a country of seven million individuals who rely predominantly on potatoes for food. Most of the Bolivian population depends on rural subsistence agriculture, but the yield of potatoes in Bolivia is ten times less than is possible with the same land area in the UK. A significant proportion of the yield gap is due to damage caused by Globodera, Meloidogyne and Nacobbus (false root knot nematode).

Several GM strategies to produce nematode-resistant plants have been investigated. One approach is the acceleration of plant breeding by transferring natural resistance genes from resistant to non-resistant plants. A useful candidate, which has been well characterised, is the tomato $\mathrm{Mi}$ gene conferring resistance to Meloidogyne spp. (Hwang et al. 2000).

Many of the strategies used to confer insect resistance also appear to work against nematodes. Cysteine proteinase inhibitors have also been shown to have nematicidal activity, since cysteine proteinases are required by nematodes for the digestion of dietary protein. The expression of a modified oryzacystatin-I gene in tomato and rice interfered with nematode development in laboratory tests (Urwin et al. 1997; Vain et al. 1998), and effective resistance has been demonstrated in field trials (Urwin et al. 2001). Some lectins are also toxic to nematodes, as demonstrated by the expression of GNA in potatoes. The number of Globodera pallida females on the transgenic potatoes was reduced to one-fifth of the level seen on non-transformed roots (Burrows et al. 1998). A preliminary study with transgenic tomato plants expressing the $B t$ toxin Cry $1 \mathrm{Ab}$ after inoculation with Meloidogyne resulted in a reduction in egg mass to one half the normal value (Burrows \& de Waele, 1997). GM varieties of several subsistence crops expressing cystatin transgenes are currently undergoing field trials in Africa (rice, banana) and Bolivia (potato). 


\section{Genetic modification targets II: abiotic stress tolerance}

After pests and diseases, unfavourable environmental conditions (abiotic stresses) represent the next major productivity constraint in the developing world. The most significant abiotic factors affecting food production are drought, poor soil quality, salinity and (in Asia) flooding. The development of crops with an inbuilt capacity to withstand these effects could help to stabilise crop production and hence significantly contribute to food security (Holmberg \& Bulow, 1998; Bray et al. 2000; Zhang et al. 2000). Furthermore, since only $35 \%$ of the world's potential arable land is currently used, the modification of plants to prosper in marginal environments could help to expand agricultural production to ensure continuing food security in the coming decades.

\section{Specific targets: drought and salinity stress}

Many plants respond to drought (prolonged dehydration) and increased salinity by synthesising small, very soluble molecules such as betaines, sugars, amino acids and polyamines. These are collectively termed compatible solutes, and they increase the osmotic potential within the plant, therefore preventing water loss in the short term and helping to maintain a normal physiological ion balance in the longer term (Yancey et al. 1982). Compatible solutes are non-toxic even at high concentrations, so transgenic approaches have been used to make them accumulate in crop plants in order to improve drought and salinity tolerance (Chen \& Murata, 2002; Serraj \& Sinclair, 2002).

Several species have been engineered to produce higher levels of glycine betaine but in most cases the levels achieved have fallen short of the 5-40 $\mu \mathrm{mol} / \mathrm{g}$ fresh weight observed in plants that naturally accumulate this molecule under salt stress conditions (Sakamoto \& Murata, 2000, 2001). However, transgenic rice plants expressing betaine aldehyde dehydrogenase, one of the key enzymes in the glycine betaine synthesis pathway, accumulated the molecule to levels in excess of $5 \mu \mathrm{mol} / \mathrm{g}$ fresh weight (Sakamoto et al. 1998). In China, transgenic rice plants expressing beatine aldehyde dehydrogenase will probably be the first commercially released GM plants developed for abiotic stress tolerance, and will be available for small-scale subsistence farmers as well as large producers (Huang et al. 2002b).

In the laboratory, the authors of the present review have studied the effects of polyamine accumulation on drought and salinity tolerance in rice and wheat. Transgenic plants with increased polyamine levels were shown to tolerate five times the amount of salt that is lethal to wild-type plants and were able to survive and perform well for $20 \mathrm{~d}$ without water while wild-type plants began to deteriorate if water was withheld for more than $4 \mathrm{~d}$ (Capell et al., unpublished results). Increased drought tolerance has also been demonstrated in potato plants accumulating high levels of the sugar trehalose. However, these plants showed unanticipated morphological changes and modification of structural carbohydrates (Yeo et al. 2000). Therefore, a careful balance has to be struck between increased stress tolerance and unwanted physiological effects on plant growth.
As well as compatible solutes, plants also produce osmoprotectant proteins known as dehydrins in response to drought and salinity stress. The overexpression of such proteins offers another strategy to generate drought-tolerant crop varieties. Xu et al. (1996) expressed the barley dehydrin HVA1 in transgenic rice, and the transgenic plants were shown to be resistant to water deficit and salt stress. More recently, several wheat dehydrins have been expressed in transgenic rice and have also been shown to increase dehydration tolerance (Cheng et al. 2001, 2002).

The overexpression of ion channels and pumps that increase the efflux of $\mathrm{Na}$ ions from the cytosol has been explored as a strategy to counteract the effects of ion stress brought about by increased salinity. The Arabidopsis NXHI gene, which encodes a vacuolar $\mathrm{Na}^{+} / \mathrm{H}^{+}$antiporter, has been overexpressed in tomato and rapeseed, and confers salt tolerance on the transgenic plants (Apse et al. 1999; Zhang \& Blumwald, 2001; Zhang et al. 2001). While the modification of single transporters is useful, manipulation of signal transduction pathways and gene regulation networks that control the response to salt stress may be more useful in the future (Hasegawa et al. 2000; Zhu, 2001).

\section{Specific targets: flooding stress (hypoxia)}

While the absence of water is detrimental to plants, too much water can also be a problem particularly in rain-fed areas where the level of precipitation can be excessive. The main consequence of flooding is an $\mathrm{O}_{2}$ deficit in the roots, which induces ethylene synthesis in the aerial parts of the plant, resulting in chlorosis, senescence and eventually death (Stearns \& Glick, 2003). The increase in ethylene synthesis in flooded plants is due to the induction of 1-aminocyclopropane-1-carboxylate (ACC) synthase. The ACC produced in the roots is transported to the aerial parts of the plant, where it is converted into ethylene by another enzyme, ACC oxidase (for a review, see Grichko \& Glick, 2001b).

Transgenic tomato plants expressing ACC deaminase, a catabolic enzyme that draws ACC away from the ethylene synthesis pathway, showed increased tolerance to flooding stress and were less subject to the deleterious effects of root hypoxia on plant growth than non-transformed plants. The most significant improvements were achieved by expressing the transgene under the control of the Agrobacterium rhizogenes root-specific rolD promoter (Grichko \& Glick, 2001a). Transgenic tomato plants have also been produced in which the endogenous ACC synthase or ACC oxidase genes have been suppressed by antisense RNA. In plants transformed with antisense ACC synthase, ethylene production was lowered to less than $1 \%$ of normal levels (John, 1997). Antisense ACC oxidase plants showed lower ethylene levels following root submergence (English et al. 1995).

\section{Specific targets: poor soil quality}

In addition to water and sunlight, mineral nutrients are essential for plant growth and development. The maintenance of soil fertility, by adding inorganic or organic sources of nutrients, has made a major contribution to the 
increase in food production over the last 40 years (Loneragen, 1997). Fertiliser use is projected to double again over the next 20 years to ensure that production continues to keep pace with population growth (Food and Agriculture Organization, 2000). However, despite increased inputs of $\mathrm{N}, \mathrm{P}$ and $\mathrm{K}$, yields of rice and wheat have started to decline in some parts of Asia. It is thought that deficiencies in other nutrients, such as $\mathrm{S}, \mathrm{Zn}$ and Fe, are responsible for this decline, and that a key to producing high yields under intensive cropping systems is a supply of mineral nutrients that is both adequate and balanced (Hossain \& Singh, 2000).

The problem of mineral exhaustion is exacerbated by poor soil quality, which locks the available nutrients into inaccessible compounds. About $65 \%$ of the world's potential arable land consists of marginal soils, which are characterised by extremes of $\mathrm{pH}$, limited nutrient availability (particularly $\mathrm{P}$ and $\mathrm{Fe}$ ) and high levels of toxic metal ions (Marshner, 1995). Acidic soils, which account for $40 \%$ of the arable land, have low levels of available $\mathrm{P}$ and $\mathrm{Fe}$ but high levels of $\mathrm{Al}$. In an acidic environment, both $\mathrm{Fe}$ and $\mathrm{Al}$ sequester $\mathrm{P}$ into insoluble or poorly soluble molecules. $\mathrm{Al}$ is also toxic in its own right, its major effect being the inhibition of root development. Alkaline soils account for $25 \%$ of arable land. The major problem in alkaline soils is the high level of $\mathrm{Ca}$ and $\mathrm{Mg}$ ions, which also sequester $\mathrm{P}$ into insoluble and sparingly soluble molecules. $\mathrm{Ca}^{2+}$ is an essential signalling molecule in plants and high levels of this metal ion can interfere with normal plant growth and metabolism.

Despite these problems, many plants have adapted to grow in marginal soils and some tolerant varieties of crop plants have also been produced by mutation and conventional breeding. A common factor among these tolerant plants is the increased exudation of organic acids, such as citrate, malate and oxalate, from the roots. These substances concentrate in the rhizosphere and are thought to have a number of protective effects, including the displacement and solubilisation of $\mathrm{P}$ and $\mathrm{Fe}$, the chelation of $\mathrm{Al}$ and the attraction to the rhizosphere of beneficial micro-organisms, which may also enhance nutrient availability (LopezBucio et al. 2000b). The production of transgenic crop plants engineered to exude higher levels of organic acids is therefore an attractive strategy to increase the use of marginal soils. The model experimental plants tobacco and Arabidopsis, as well as the important developing country food crop papaya, have been transformed with bacterial or plant citrate synthase genes to increase organic acid production and induce tolerance of poor soils (de la Fuenete \& Herrera-Estrella, 1997; Koyoma et al. 2000; Lopez-Bucio et al. 2000a). The analysis of root extracts by HPLC showed that citrate levels were ten times higher than normal, but more importantly, the levels of citrate recorded in root exudates were four times the normal level. These plants could grow in the presence of $\mathrm{Al}$ ions at ten times the concentration sufficient to suppress the growth of nontransformed plants, and there was no evidence of $\mathrm{Al}$ induced root damage. The transgenic plants also performed better in alkaline soils. They grew and flowered normally and produced seeds, whereas control plants showed restricted vegetal growth and failed to produce flowers or seeds (Lopez-Bucio et al. 2000a). The exudation of phytase from the roots of transgenic plants can be used to release $\mathrm{P}$ locked away in organic compounds, since much of the organic $\mathrm{P}$ in soil is present as phytate (Hayes et al. 1999). Initial experiments with Arabidopsis plants secreting phytase from the roots showed that the transgenic plants were able to grow much better than control plants on phytate medium. The development of crop plants that secrete phytase and organic acids is therefore an important goal for the future.

\section{Genetic modification targets III: lifting the yield ceiling}

Much of the success of the Green Revolution was due to the development of semi-dwarf varieties of rice and wheat with biomass accumulation diverted away from vegetative tissues and towards grains (Chrispeels \& Sadava, 2003). With increasing knowledge of the genes that control plant growth and development, an emerging strategy to increase yields still further is to use GM technology for the manipulation of plant architecture. This not only has the potential to increase the harvest index (usable biomass:waste ratio), but can help to increase yields in other ways; for example, by altering the number, shape and angle of leaves to maximise the efficiency of light use in crowded fields. The control of plant development is only one of several approaches whose overall aim is to increase the amount of fixed $\mathrm{C}$ in photosynthetic sink tissues. Further approaches include the manipulation of plants to increase the efficiency of nutrient uptake, which in many cases overlaps with strategies aiming to improve the performance of crops on marginal or depleted soils. Photosynthesis is also a useful target for improvement, as is the control of $\mathrm{C}$ partitioning between sucrose, starch and amino acids. This section of the review considers a diverse range of approaches for yield improvement, which in combination with traditional measures could have a major impact on food security in the coming decades. An important but often overlooked component of this strategy is the exploitation of genes for male sterility and apomixis to produce stable, high-yielding hybrids.

\section{Increasing the efficiency of photosynthesis}

In terms of yield enhancement, photosynthesis is perhaps the most obvious target for genetic intervention because it determines the rate of $\mathrm{C}$ fixation, and therefore the overall size of the organic C pool. Strategies for increasing photosynthetic activity include the modification of light-harvesting phytochromes and key photosynthetic enzymes. Most work has been carried out in tobacco because the technology for gene transfer to chloroplasts is most advanced in this species, but there have been some attempts to transfer the technological approach to important food crops resulting in higher yields.

In an example of phytochrome engineering, transgenic potato plants expressing an Arabidopsis phytochrome cDNA showed a reduced shade response, limiting the stem height even under crowded conditions and thus diverting more biomass towards the tubers. The rate of photosynthesis also improved due to an increase in the number of chloroplasts (Thiele et al. 1999). Attempts to modify the 
major enzymes responsible for photosynthate assimilation, i.e. Rubisco and the enzymes of the Calvin cycle, have been restricted mainly to tobacco (for example, Miyagawa et al. 2001; Whitney \& Andrews, 2001). However, progress has been made in crop species by attempting to introduce components of the energy-efficient $\mathrm{C}_{4}$ photosynthetic pathway into $\mathrm{C}_{3}$ plants, which loose a proportion of their fixed $\mathrm{C}$ through photorespiration. The key step in $\mathrm{C}_{4}$ photosynthesis is the conversion of $\mathrm{CO}_{2}$ into $\mathrm{C}_{4}$ organic acids by the enzyme phosphoenolpyruvate carboxylase (PEPC) in mesophyll cells. The maize gene encoding PEPC has been transferred into several $\mathrm{C}_{3}$ crops, including potato (Ishimaru et al. 1998) and rice (Matsuoka et al. 1998; Ku et al. 1999) in order to increase the overall level of C fixation. Transgenic rice plants were also produced expressing pyruvate orthophosphate dikinase and NADP-malic enzyme (Ku et al. 1999). Preliminary field trials in China and Korea demonstrated 10-30\% and 30-35\% yield increases for PEPC and pyruvate orthophosphate dikinase transgenic rice plants, respectively, which was quite unexpected since only one $\mathrm{C}_{4}$ enzyme was expressed in each case. In the PEPC transgenic plants, there was also an unanticipated secondary effect in which Rubisco showed reduced inhibition by $\mathrm{O}_{2}$ ( $\mathrm{Ku}$ et al. 1999).

\section{Engineering carbon metabolism}

Metabolic approaches to increase overall yields focus on the conversion of sugars, representing the direct products of photosynthesis, to the bioavailable storage carbohydrate starch. Several different strategies have been attempted. These include the manipulation of enzyme activity and regulation in source tissues to increase the C flux to sink tissues (Paul et al. 2001), increasing the efficiency of sugar transport to sink tissues (Rosche et al. 2002) and the manipulation of enzyme activity in the sink tissue itself to increase the conversion of photoassimilates into starch. Transgenic approaches to increase sugar to starch conversion have focused primarily on the modulation of sucrose metabolism or on the manipulation of the plastidial starch synthesis pathway. Most progress has been made in potato where starch metabolism has been studied in particular detail.

To date, the most successful approaches have been those targeted at the plastidially localised reactions with plants overproducing either an unregulated bacterial ADP-glucose pyrophosphorylase (Stark et al. 1992) or the Arabidopsis amyloplastidial ATP-ADP translocator (Tjaden et al. 1998), both of which led to a marked increase (up to $150 \%$ ) in starch accumulation. Inhibition of the plastidial adenylate kinase in transgenic potatoes resulted in a substantial increase in the level of adenylates and a $60 \%$ increase in the level of starch, in combination with a $40 \%$ increase in tuber yield (Regierer et al. 2002). In addition, the concentrations of several amino acids were increased by a factor of two to four. Attempts have also been made to improve starch yield by producing a more efficient pathway of sucrose degradation, consisting of either a yeast invertase and a bacterial glucokinase (Sonnewald et al. 1997; Trethewey et al. 1998) or a bacterial sucrose phosphorylase (Trethewey et al. 1998). The rationale behind this approach is to supply a large pool of immediate substrates for ADPglucose pyrophosphorylase. However, these attempts actually reduced starch accumulation in the transgenic plants and further studies suggested that glycolysis was activated resulting in the respiration of the stored starch. Ehrhardt $e t$ al. (2001) have shown that an overall increase in the level of stored carbohydrates in plants can be achieved by overexpressing dihydro-orotase, a gene of pyrimidine metabolism. In a similar study designed to improve the storage capacity of potato tubers, the enzymes $\alpha$-glucan L-type phosphorylase and $\alpha$-glucan $\mathrm{H}$-type phosphorylase have been inhibited. Transgenic tubers demonstrated a reduced conversion of starch to sugar during storage, thus increasing the storage life as well as increasing the carbohydrate content. Improved yield can also be achieved by expressing the bacterial enzyme fructose-1,6-bisphosphate aldolase, which reversibly catalyses the conversion of triosephosphate to fructose-1,6-bisphosphate. Transgenic plants expressing Escherichia coli fructose-1,6-bisphosphate aldolase showed higher levels of starch at the expense of sugar concentration, and a greater root mass (Barry et al. 1998). Smidansky et al. (2002, 2003) have shown that wheat and rice plants transformed with a modified form of the maize gene for ADP-glucose pyrophosphorylase (shrunken2) showing resistance to inhibition by orthophosphate have about $40 \%$ (wheat) and $20 \%$ (rice) more seed biomass than wild-type controls.

\section{Plant architecture}

Plant architecture has a significant effect on crop yields because it influences many characteristics, such as height, the size, number and arrangement of leaves, and the structure of the root system. All of these may affect plant performance in terms of strength, efficiency of nutrient uptake and capacity for $\mathrm{C}$ fixation, resulting in better yields. Particularly in cereals, erect leaves are desirable because plants bearing such leaves can be planted densely, yet still perceive sunlight efficiently. Plants with short stems generally have a better harvest index than long-stemmed plants because more biomass is diverted to the reproductive tissues, and such plants are also more resistant to lodging. These traits are controlled by plant hormones and one major transgenic strategy, discussed below, is the manipulation of hormone signalling pathways to generate plants with agronomically useful characteristics. Others include the manipulation of developmental regulator genes and genes that control the cell cycle. Some case studies are discussed later (p. 33).

Gibberellin signalling. The Green Revolution saw the widespread adoption of semi-dwarf rice, wheat and maize varieties, which have since been shown to carry mutations in orthologues of the Arabidopsis gibberellic acid (GA)insensitive gene. This encodes a negative regulator of GA signal transduction (Peng et al. 1999). In normal cereals, the increased use of fertiliser leads to better grain weights but it also increases culm (stem) elongation and the overall height of the plant, making such plants susceptible to lodging. Semi-dwarf varieties show increased grain yields without culm elongation, and this is highly desirable, especially 
in the monsoon regions of Asia where high winds and heavy rain cause extensive crop damage.

The transfer of a mutant Arabidopsis GA-insensitive gene into rice is sufficient to induce a dominant semidwarfing phenotype (Peng et al. 1999; Fu et al. 2001). This suggests that the manipulation of GA signalling could be a useful approach to increase yields in a wide variety of plants. Related strategies include the manipulation of genes involved in GA synthesis or those regulated by GA. For example, GA2-oxidase plays an important role in the regulation of plant growth by reducing endogenous levels of bioactive GA. A rice GA2-oxidase gene, OsGA2oxl, has been cloned and introduced into wild-type plants leading to the inhibition of stem elongation (Sakamoto et al. 2001). Similarly, GA $3 \beta$-hydroxylase increases the levels of bioactive GA. The rice gene for GA $3 \beta$-hydroxylase, OsGA3ox2, has been isolated (Itoh et al. 2001) and antisense transgenes introduced into wild-type plants, producing a dominant semi-dwarf phenotype.

Brassinosteroid signalling. Brassinosteroids are plant hormones found at low levels in pollen, seeds and young vegetative tissues, which regulate gene expression, stimulate cell division and cause differentiation (Clouse \& Sasse, 1998). Analysis of a dwarf rice mutant with unusually erect leaves led to the identification of OsBRI1, the rice orthologue of the Arabidopsis brassinosteroid receptor protein Bri1 (Yamamuro et al. 2000). Transgenic plants expressing antisense OsBRII cDNA under the control of a constitutive promoter have erect leaves and a severe dwarf phenotype (Yamamuro et al. 2000). In order to reduce the severity of this phenotype, an alternative strategy has been used in which a dominant negative OsBRI1 protein was expressed to inhibit but not abolish brassinosteroid signalling. Rice plants were transformed with the kinase domain of the OsBRI1 protein and the resulting plants, constitutively expressing the transgene, had erect leaves without dwarfism. No other differences between the transgenic and wild-type plants were observed. Modelling suggests that $50 \%$ more rice could be grown in the same area with no loss of yield, although this remains to be demonstrated in field trials (Ashikari \& Matsuoka, 2002).

Manipulation of plant development. The manipulation of developmental regulator genes has received less attention than the disruption of hormonal signalling because there is still relatively little information about the roles of developmental genes in crop species. However, there have been some interesting advances that may prove important in the future. For example, homeotic genes such as $Z M M 8$ and $Z M M 14$, which determine spikelet identity in maize, could be used to boost seed numbers in other cereals (Cacharrón et al. 1999). Similarly, many of the genes that control the formation of root hairs have been identified in Arabidopsis, and these could be used to produce GM plants with supernumerary hairs, which would be better able to exploit nutrient resources in the soil (Szymanski et al. 2000).

Plant development can also be influenced by modifying the activity of cell-cycle genes to control cell division. A number of plant cyclins and cyclin-dependent kinases have been ectopically expressed with varying effects on pheno- type (den Boer \& Murray, 2000). For example, Arabidopsis $c y c B 1$ overexpression led to enhanced root growth, a characteristic that could be exploited in crop plants for lodging resistance and increased nutrient uptake (Doerner et al. 1996). Similarly increased lateral root formation was observed in tobacco plants expressing yeast $c d c 25$ (McKibbin et al. 1998). Other characteristics influenced by the manipulation of cell-cycle genes include flowering time (see below), cell size and ploidy, all of which have been shown to be related to crop yields.

\section{Early maturation}

Early maturation phenotypes are desirable because they allow early harvesting, which may avoid the exposure of crops to some of the biotic and abiotic stresses discussed earlier in the present article (pp. 24-31). Furthermore, for plants that are harvested several times a year, early maturation may allow extra cropping cycles. Arabidopsis mutants that flower either early or late have identified regulatory genes whose expression could be exploited in crops to induce early flowering. Many of the Arabidopsis floweringtime genes encode transcription factors with a MADS box motif, which is highly conserved in all eukaryotes. It has therefore been relatively simple to isolate orthologous genes from crop plants and manipulate their expression in transgenic plants. In this way, it has been shown that the rice MADS box genes OsMADS1, OsMADS5, OsMADS7, and OsMADS8 can induce floral meristems when overexpressed in tobacco (Chung et al. 1994; Kang \& An, 1997; Kang et al. 1997). Similarly, Arabidopsis APETELLAl and AGAMOUS were shown to initiate floral meristems (Mandel \& Yamovsky, 1995; Mizukami \& Ma, 1997). An apple MADS box gene, MdMADS2, also induced premature flowering in tobacco (Sung et al. 1999). More recently, several rice MADS box genes of the APETELLA1/AGAMOUS-LIKE9 (AGL9) group (OsMADS1, OsMADS5, OsMADS6, OsMADS7, OsMADS8 and OsMADS14) have been shown to promote both early flowering and cause dwarf phenotypes in transgenic rice (Jeon et al. 2000).

\section{Nutrient acquisition and accumulation}

The manipulation of plant growth and development to optimise light interception, and the optimisation of the photosynthetic machinery itself, can be thought of as a series of measures to increase $\mathrm{C}$ flux from atmospheric $\mathrm{CO}_{2}$ to energy-rich molecules eventually consumed as food. However, many other nutrients are required for efficient plant growth, the most important of which are N, P, K and S (Hill \& Hillebrand, 2001). In agricultural systems these are usually applied as fertiliser, so little attention has been given to the efficiency with which plants take up these molecules from the environment. Plants that acquire and accumulate nutrients more efficiently are desirable not only because of the potentially higher yields that could be achieved on the same amount of land, but because they will reduce reliance on fertilisers.

At the present time, the application of transgenic technology to plant nutrient uptake is in its infancy. It is also important to realise that increasing the uptake of nutrients 
only serves to create an inorganic nutrient pool in the plant, which may be toxic. Therefore, it is also necessary to optimise the assimilation of these molecules into non-toxic organic molecules. Another consideration is the control of ion efflux, to stop inorganic nutrient pools leaching out of the plant. Many plants undergo local changes to root morphology in response to nutrient availability, and the import of such developmental capabilities into crops might be useful to exploit 'pockets' of nutrients in marginal soils (see Stitt, 1999).

The overexpression of nitrate transporters has been demonstrated but only for the purpose of dissecting the regulation of $\mathrm{N}$ metabolism, not for the agricultural improvement of crops (Huang et al. 1999; Fraisier et al. 2000). While increasing the uptake of nitrate is a necessary step, the accumulation of free nitrate ions in edible plant organs will make them toxic. Any increase in nitrate uptake must therefore be matched by an increase in nitrate assimilation into N-rich organic molecules, as has been achieved by the overexpression of glutamine synthetase and glutamine dehydrogenase in transgenic tobacco and maize plants (Lightfoot et al. 1998; Harrison et al. 2000).

Guo et al. (1998) have reported the transformation of rice with a Parasponia haemoglobin gene in order to create the low $\mathrm{O}_{2}$ environment required to protect nitrogenase from $\mathrm{O}_{2}$ damage. This may facilitate associations between Rhizobium strains and rice, providing the first step towards the goal of $\mathrm{N}$-fixing cereals.

The high-affinity phosphate transporter from Arabidopsis has been overexpressed in cultured tobacco cells resulting in enhanced uptake capacity and biomass accumulation even in a phosphate-depleted medium (Mitsukawa et al. 1997). Some components of the phosphate-response signalling pathway have also been identified in Arabidopsis, and these could provide further tools for the regulation of phosphate uptake in future GM crops (Huang et al. 2000). Thus far there have been no reports of transgenic plants expressing sulfate transporters or components of the sulfate-detecting signal transduction pathway although a number of candidates have been identified (for example, see Davies et al. 1999).

\section{Genetic modification targets IV: increasing the nutritional value of food}

Food security depends not only on the quantity of food available but also on its nutritional quality. Unfortunately, the poorest individuals in the world are faced with a limited choice, and generally rely on a single staple food crop for their energy intake. Most plants are deficient in some essential amino acids, vitamins and minerals but a balanced diet provides adequate quantities of all. Problems arise when the diet is restricted to a single protein source, which is often the case for both human populations and domestic animals in developing countries (Graham et al. 2001). For example, cereal storage proteins are deficient in lysine and threonine while legumes tend to lack the S-containing amino acids methionine and cysteine. A diet solely comprising one of these protein sources will therefore be deficient for one or more essential amino acids. Milled cereal grains are also deficient in several vitamins and minerals, the most important of which are vitamin $\mathrm{A}, \mathrm{Fe}$ and $\mathrm{Zn}$. GM strategies to provide nutrient fortification represent one of the most straightforward approaches to alleviate malnutrition, and three case studies are considered below.

\section{Increasing the content of vitamin A in rice}

Vitamin A deficiency is prevalent in the developing world, and is probably responsible for the death of 2 million children every year. In surviving children, vitamin A deficiency is a leading, but avoidable, cause of blindness (World Health Organization, 2001). Man can synthesise vitamin $A$ if provided with the precursor molecule $\beta$-carotene (also known as provitamin A), a pigment found in many plants but not cereal grains. Therefore, a strategy was devised to introduce the correct metabolic steps into rice endosperm to facilitate $\beta$-carotene synthesis. The synthesis of carotenes in plants is a branch of the isoprenoid pathway and the first committed step is the joining of two geranylgeranyl diphosphate molecules to form the precursor phytoene. The conversion of phytoene into $\beta$-carotene requires three additional enzyme activities: phytoene desaturase, $\beta$ carotene desaturase and lycopene $\beta$-cyclase. Rice and other cereal grains accumulate geranylgeranyl diphosphate but lack the subsequent enzymes in the pathway, so the genes for all three enzymes are required.

The first major breakthrough was the development of rice grains accumulating phytoene. Burkhardt et al. (1997) described rice plants transformed with the phytoene synthase gene from the daffodil (Narcissus pseudonarcissus) that accumulated high levels of this metabolic intermediate. Further work by the same group (Ye et al. 2000) resulted in rice plants expressing two daffodil genes and one bacterial gene, which recapitulated the entire heterologous pathway. The transgenic rice grains were golden in colour because they were highly enriched in $\beta$-carotene; the best cases contained more than $1.5 \mu \mathrm{g} \beta$-carotene/g dry weight of grain.

The 'Golden Rice' project represents not just a technological breakthrough but a triumph of humanitarian science that should be used as a model for the development and deployment of other GM varieties in the developing world. From the beginning, the clear aim of the project organisers was to maintain freedom to operate and to provide the technology free of charge to subsistence farmers in developing countries, a feat that required careful negotiation over more than 100 intellectual and technical property rights (Potrykus, 2001). Golden Rice fulfils an urgent need; it complements traditional interventions and provides a real opportunity to address a significant world health problem. It was developed to benefit the poor and disadvantaged and will be given to subsistence farmers with no attached conditions. It requires no additional inputs compared with other rice varieties. Since the original report, further Golden Rice lines have been generated containing only two foreign enzymes (daffodil phytoene synthase and bacterial phytoene desaturase; Beyer et al. 2002). Furthermore, these lines have been generated with the innocuous selectable marker mannose phosphate isomerase, therefore avoiding the use of antibiotic or herbicide resistance markers that are considered by some to pose a perceived health risk (Lucca 
et al. 2001b). Transgenic tomatoes with an elevated content of provitamin A have also been reported (Romer et al. 2000), as well as plants with increased levels of vitamin C (Hunter, 2001) and vitamin E (Shintani \& DellaPenna, 1998). Still, Golden Rice attracts criticism from pressure groups, mainly because they regard it as the start of a slippery slope towards the acceptance of other GM foods, and it has been suggested that different measures, such as dietary diversity, vitamin supplements or fortification should be considered instead. A comprehensive discussion of the potential benefits and limitations of Golden Rice is presented by van Wijk (2002).

\section{Increasing the content of essential amino acids}

Since much of the world's population relies on cereals as essentially the sole dietary intake there has been much interest in the development of high-lysine cereal varieties. There has been some success with conventional breeding (for example, the opaque 2 mutant of maize) but transgenic strategies have been applied to a greater range of crops. One of the first breakthroughs was the antisense inhibition of prolamin synthesis (prolamins are abundant storage proteins but they contain little lysine), leading to the replacement of prolamins with endogenous lysine-rich proteins. Unfortunately, this strategy tended to reduce overall yields by inhibiting starch synthesis.

A more direct approach (Wallace et al. 1988) is the modification of cereal storage-protein genes to incorporate codons for lysine and threonine, and also tryptophan (which is generally limiting in most plants). There are two major drawbacks to this approach. First, cereal-storage proteins are encoded by a large gene family in each plant, so the manipulation of one gene makes little impact on the overall protein composition of the seed unless a strategy can be devised to preferentially express the modified gene. Second, part of the reason for the low content of lysine and other amino acids in cereals is the limited free lysine pool. This also affects another strategy for increasing the lysine content of cereals, which is the expression of specific, lysine-rich proteins. Such proteins may be naturally occurring plant proteins, natural proteins that have been modified to increase the number of lysine residues, or even fully synthetic proteins. For example, pea legumin and soyabean glycinin, both of which have high lysine contents, have been expressed successfully in rice and wheat grains (Sindhu et al. 1997; Stoger et al. 2001).

The most successful experiments have tackled the problem of low lysine content directly, by increasing the availability of free lysine in the plant. In all higher plants, the amino acids lysine and threonine (as well as isoleucine and methionine) are synthesised from aspartic acid. The pathway is highly branched and under complex feedback control. Two principal enzymes are aspartate kinase, which acts early in the pathway and is inhibited by both lysine and threonine, and dihydrodipicolinate synthase, which acts in the lysine-specific branch and is inhibited by lysine alone. Feedback-insensitive versions of the enzymes have been expressed in cereals by introducing bacterial transgenes. For example, Falco et al. (1995) showed that transgenic soyabean expressing bacterial dihydrodipicolinate synthase and aspartate kinase enzymes had levels of free lysine five times higher than non-transgenic plants. Similarly, the expression of dihydrodipicolinate synthase in maize increases the levels of free lysine from less than $2 \%$ to almost $30 \%$ of the free amino acid pool, with concomitant increases in threonine (Falco, 1998).

More recently, expression of the AmAl seed albumin gene from Amaranthus hypochondriacus in potato has been shown to double the protein content and increase the content of essential amino acids (Chakraborty et al. 2000). The AmAl coding sequence was successfully introduced and expressed in a tuber-specific and constitutive manner, leading to a striking increase in the growth and production of tubers. The modified potato, as for Golden Rice, has been developed with the poor and hungry in mind and is awaiting approval for use in India's 15-year plan to combat poverty and malnutrition in children.

\section{Increasing the content of iron}

Fe deficiency is the most prevalent form of mineral deficiency around the world, even in developed countries, and causes severe anaemia particularly in women and children (Graham et al. 2001). In the developed world, mineral deficiency is prevented by balanced diets, mineral supplements (for example, Fe pills) and fortification (for example, the addition of I to table salt). In developing countries, such countermeasures do not exist and since cereals and legumes are naturally deficient in minerals such as Fe and $\mathrm{Zn}$, there is widespread anaemia and other diseases caused by mineral deficiency. Transgenic plants with increased mineral levels provide one solution to this problem, and there have been some encouraging results with plants designed to accumulate $\mathrm{Fe}$ (Cakmak, 2002). This can be achieved by increasing $\mathrm{Fe}$ uptake from the environment (for example, through the activation of $\mathrm{Fe}$ transporters) or by increasing the capacity of plants to store Fe. Thus far, only the second strategy has been explored. Goto et al. (1999) expressed the soyabean ferritin gene, encoding an Fe storage protein, in transgenic rice using a glutelin promoter that restricted transgene expression to the endosperm. This resulted in a threefold increase in Fe levels in rice grains. In contrast, the use of a constitutive promoter to drive ferritin expression resulted in elevated Fe levels in the leaves of transgenic rice plants, but not grains (Drakakaki et al. 2000).

While the total amount of $\mathrm{Fe}$ and other minerals in plants is an important determinant of nutritional quality, what really matters is the amount of bioavailable $\mathrm{Fe}$ and how well it is absorbed by the human gut. Lucca et al. (2001a) described a combined approach in which the amount of bioavailable $\mathrm{Fe}$ could be increased. Transgenic rice plants were produced expressing a bean ferritin gene, encoding a protein that is known to store $\mathrm{Fe}$ in a bioavailable form. The plants also expressed a cysteine-rich metallothionein protein belonging to a family of proteins that are thought to enhance $\mathrm{Fe}$ absorption from the gut. Finally, the plants also expressed Aspergillus phytase, an enzyme that degrades phytic acid which is considered to limit Fe uptake as well as the utilisation of other nutrients. These rice plants had twice the Fe levels of normal plants although the bioavailability remains to be tested. 


\section{Conclusions}

Advances in plant transformation and gene expression technology allow the introduction of novel traits into crop plants. Genetically enhanced crops have the potential to address some of the causes of hunger, both directly (by increasing the availability of food) and indirectly (by reducing poverty in developing countries). Crop failure, due to pests and diseases, could be averted by the adoption of plants that are resistant to such biotic stresses. The development of plants that are tolerant of extreme environments could allow marginal soils to be brought into agricultural use, and could allow plants to survive periods of drought or flooding. The modification of plant architecture could increase yields and sturdiness by diverting biomass from stems and stalks to the edible organs. Overall yields could be increased by manipulating photosynthesis, $\mathrm{C}$ and $\mathrm{N}$ metabolism or by modifying plant development to promote early flowering and multiple growth cycles annually. Exhausted soils could be sown with crops that are better able to extract nutrients, and contaminated soils could be regenerated by plants developed for bioremediation. These measures, in combination with conventional breeding and developments in other agricultural practices, may produce the estimated $50 \%$ increase in grain yields required over the next 50 years to cope with the anticipated increase in population.

Transgenic strategies can also be used to modify the nutritional properties of plants and address the widespread problem of malnutrition in developing countries. The harvestable products of plants can be improved by promoting the uptake, accumulation or synthesis of bioavailable minerals and vitamins, by increasing or modifying the content of amino acids and fats and oils, and by eliminating antinutritional factors. Golden Rice, a GM strain of rice engineered to produce provitamin A, provides a model for the development of nutritionally enhanced crops for the subsistence farmers of developing countries.

The present review has focused on technology and purposely steered clear of the political and trade issues that erect barriers to the wider adoption of GM-enhanced crops in the developing world. However, politics and trade have always been closely associated with agricultural production and distribution. Regrettably these have made GM crops a political football between the European Union and the USA, with the playing field being shifted to Southern African states on the verge of starvation. Recent controversy centred on the refusal of some African states to accept American aid in the form of GM food, for no other reason other than political pressure from certain European Union quarters. This is not only inexcusable and hypocritical but also unethical. It is hoped that in time the value of GM crops, as a component of a serious drive focusing on sustainability, will contribute significantly to the improvement of food security in the developing world.

\section{References}

Alam MF, Datta K, Abrigo E, Vasquez A, Senadhira D \& Datta SK (1998) Production of transgenic deep water indica rice plants expressing a synthetic Bacillus thuringiensis CryIA(b) gene with enhanced resistance to yellow stem borer. Plant Science 35, 25-30.
Amsellum Z, Cohen BA \& Gressel J (2002) Engineering hypervirulence in a mycoherbicidal fungus for efficient weed control. Nature Biotechnology 20, 1035-1039.

Apse MP, Aharon GS, Snedden WA \& Blumwald E (1999) Salt tolerance conferred by overexpression of a vacuolar $\mathrm{Na}^{+} / \mathrm{H}^{+}$ antiport in Arabidopsis. Science 285, 1256-1258.

Ashikari M \& Matsuoka M (2002) Application of rice genomics to plant biology and breeding. Botanical Bulletin of Academia Sinica 43, 1-11.

Bano-Maqbool S, Husnain T, Riazuddin S, Masson L \& Christou P (1998) Effective control of yellow stem borer and rice leaf folder in transgenic rice indica varieties Basmati-370 and M7 using the novel $\delta$-endotoxin Cry2A Bacillus thuringiensis gene. Molecular Breeding 4, 501-507.

Bano-Maqbool S, Riazuddin S, Loc NT, Gatehouse AMR, Gatehouse JA \& Christou P (2001) Expression of multiple insecticidal genes confers broad resistance against a range of different rice pests. Molecular Breeding 7, 85-93.

Barry GF, Cheikh N \& Kishore G (1998) Expression of fructose1,6-bisphosphate aldolase in transgenic plants. Patent application WO 98/58 069.

Bent AF (1996) Plant disease resistance genes: function meets structure. Plant Cell 8, 1757-1771.

Berner DK, Kling JG \& Singh BB (1995) Striga research and control: a perspective from Africa. Plant Disease 79, 652-660.

Beyer P, Al-Babili S, Ye X, Lucca P, Schaub P, Welsch R \& Potrykus I (2002) Golden Rice: introducing the $\beta$-carotene biosynthesis pathway into rice endosperm by genetic engineering to defeat vitamin A deficiency. Journal of Nutrition 132, 506S-510S.

Bohorova N, Frutos R, Royer M, Estanol P, Pacheco M, Rascon Q, McLean S \& Hoisington D (2001) Novel synthetic Bacillus thuringiensis crylB gene and the $c r y l B$-crylAb translational fusion confer resistance to southwestern corn borer, sugarcane borer and fall armyworm in transgenic tropical maize. Theoretical and Applied Genetics 103, 817-826.

Bowles DJ (1990) Defense-related proteins in higher plants. Annual Review of Biochemistry 9, 873-907.

Bray EA, Bailey-Serres J \& Weretilnyk E (2000) Responses to abiotic stress. In Biochemistry and Molecular Biology of Plants, pp. 1158-1203 [BB Buchanan, W Gruissem and RL Jones, editors]. Rockville, MD: American Society of Plant Pathologists.

Burkhardt PK, Beyer P, Wunn J, Kloti A, Armstrong GA, Schledz M, vonLintig J \& Potrykus I (1997) Transgenic rice (Oryza sativa) endosperm expressing daffodil (Narcissus pseudonarcis$s u s$ ) phytoene synthase accumulates phytoene, a key intermediate of provitamin A biosynthesis. The Plant Journal 11, 1071-1078.

Burrows PR, Barker ADP, Newell CA \& Hamilton WDO (1998) Plant-derived enzyme inhibitors and lectins for resistance against plant-parasitic nematodes in transgenic crops. Pesticide Science 52, 176-183.

Burrows PR \& de Waele D (1997) Engineering resistance against plant parasitic nematodes using anti-nematode genes. In Cellular and Molecular Aspects of Plant-Nematode Interactions, pp. 217-236 [C Fenoll, F Grundler and S Ohl, editors]. Dordrecht, The Netherlands: Kluwer Academic Publishing.

Byerlee D, Heisey P \& Pingali PL (2000) Realizing yield gains for food staples in developing countries in the early 21 st century: prospects and challenges. In Food Needs of the Developing World in the Early 21st Century, pp. 207-250 [TT Chang, BM Colombo and MS Sorondo, editors]. Vatican City: Political Academy of Sciences.

Byrnes BH \& Bumb BL (1998) Population growth, food production and nutrient requirements. In Journal of Crop Production, pp. 1-27 [Z Rengel, editor]. New York: Haworth Press. 
Cacharrón J, Saedler H \& Theissen G (1999) Expression of MADS box genes ZMM8 and ZMM14 during inflorescence development of Zea mays discriminates between the upper and the lower floret of each spikelet. Development Genes and Evolution 209, 411-420.

Cakmak I (2002) Plant nutrition research: priorities to meet human needs for food in sustainable ways. Plant and Soil 247, 3-24.

Carpenter JE \& Gianessi LP (2001) Agricultural Biotechnology: Updated Benefit Estimates, pp.1-46. Washington, DC: National Center for Food and Agricultural Policy.

Cary JW, Rajasekaran K, Jaynes JM \& Cleveland TE (2000) Transgenic expression of a gene encoding a synthetic antimicrobial peptide results in inhibition of fungal growth in vitro and in planta. Plant Science 154, 171-181.

Chakraborty S, Chakraborty N \& Datta A (2000) Increased nutritive value of transgenic potato by expressing a nonallergenic seed albumin gene from Amaranthus hypochondriacus. Proceedings of the National Academy of Sciences USA 97, 3724-3729.

Chang M-M, Chiang CC, Martin MW \& Hadwiger LA (1993) Expression of a pea disease resistance response gene in the potato cultivar Shepody. American Potato Journal 70, 635-647.

Chen THH \& Murata N (2002) Enhancement of tolerance of abiotic stress by metabolic engineering of betaines and other compatible solutes. Current Opinion in Plant Biology 5, 250-257.

Chen WP, Chen PD, Liu DJ, Kynast R, Friebe B, Velazhahan R, Muthukrishnan S \& Gill BS (1999) Development of wheat scab symptoms is delayed in transgenic wheat plants that constitutively express a rice thaumatin-like protein gene. Theoretical and Applied Genetics 99, 755-760.

Cheng X, Sardana R, Kaplan H \& Altosaar I (1998) Agrobacterium transformed rice plants expressing synthetic Cry IA (b) and Cry IA (c) genes are highly toxic to stripe and stem borer and yellow stem borer. Proceedings of the National Academy of Sciences USA 95, 2767-2772.

Cheng Z, Targolli J, Huang X \& Wu R (2002) Wheat LEA genes, PMA80 and PMA1959, enhance dehydration tolerance of transgenic rice (Oryza sativa L.). Molecular Breeding 10, 71-82.

Cheng ZQ, Targolli J, Su J, He CK, Li F \& Wu R (2001) Transgenic approaches for generating rice tolerant of dehydration stress. In Rice Genetics IV, pp. 433-438 [GS Khush, DS Brar and B Hardy, editors]. New Delhi, India: Science Publishers.

Chrispeels MJ, de Sa Grossi M \& Higgins TJV (1998) Genetic engineering with $\alpha$-amylase inhibitors makes seeds resistant to bruchids. Seed Science Research 8, 257-263.

Chrispeels MJ \& Sadava DE (2003) Plants, Genes, and Crop Biotechnology, 2nd ed. Boston, MA: Jones \& Bartlett Publishers.

Chung Y-Y, Kim S-R, Finkel D, Yanofsky MF \& An G (1994) Early flowering and reduced apical dominance result from ectopic expression of a rice MADS box gene. Plant Molecular Biology 26, 657-665.

Clouse SD \& Sasse JM (1998) Brassinosteroids: essential regulations of plant growth and development. Annual Review of Plant Physiology and Plant Molecular Biology 49, 427-451.

Datta K, Vasquez A, Tu J, Torrizo L, Alam MF, Oliva N, Abrigo E, Khush GS \& Datta SK (1998) Constitutive and tissue-specific differential expression of the $\operatorname{CryIA}(b)$ gene in transgenic rice plants conferring resistance to rice insect pest. Theoretical and Applied Genetics 97, 20-30.

Datta K, Velazhahan R, Oliva N, Ona I, Mew T, Khush GS, Muthukrishnan S \& Datta SK (1999) Overexpression of cloned rice thaumatin-like protein (PR-5) in transgenic rice plants enhances environmental-friendly resistance to Rhizoctonia solani causing sheath blight disease. Theoretical and Applied Genetics 98, 1138-1145.

Davies JP, Yildiz FH \& Grossman AR (1999) Sac3, an Snf1-like serine/threonine kinase that positively and negatively regulates the responses of Chlamydomonas to sulfur limitation. Plant Cell 11, 1179-1190.

De Feyter R, Young M, Schroeder K, Dennis E \& Gerlach W (1996) A ribozyme gene and an antisense gene are equally effective in conferring resistance to tobacco mosaic virus on transgenic tobacco. Molecular and General Genetics 250, 329-338.

de la Fuenete JM \& Herrera-Estrella L (1999) Advances in the understanding of aluminum toxicity and the development of aluminum-tolerant transgenic plants. Advances in Agronomy 66, 103-120.

De Maagd RA, Bosch D \& Stiekema W (1999) Bacillus thuringiensis toxin-mediated insect resistance in plants. Trends in Plant Science 4, 9-13.

Den Boer BGW \& Murray JAH (2000) Control of plant growth and development through manipulation of cell-cycle genes. Current Opinion in Biotechnology 11, 138-145.

Department for International Development (2002) Eliminating Hunger: Strategy for Achieving the Millennium Development Goal on Hunger. London, UK: DFID.

Doerner P, Jorgensen J-O, You R, Steppuhn J \& Lamb C (1996) Control of root growth and development by cyclin expression. Nature 380, 520-523.

Drakakaki G, Christou P \& Stoger E (2000) Constitutive expression of soybean ferritin cDNA in transgenic wheat and rice results in increased iron levels in vegetative tissues but not in seeds. Transgenic Research 9, 445-452.

Duke SO, Scheffler BE, Dayan FE \& Dyer WE (2002) Genetic engineering crops for improved weed management traits. Crop Biotechnology ACS Symposium Series 829, 52-66.

Ehrhardt TS, Nigel M, Geigenberger PL, Loef I, Zrenner R \& Schroeder M (2001) Increasing the polysaccharide content in plants. Patent application WO 01/14569.

English PJ, Lycett GW, Roberts JA \& Jackson MB (1995) Increased 1-aminocyclopropane-1-carboxylic acid oxidase activity in shoots of flooded tomato plants raises ethylene production to physiologically active levels. Plant Physiology 109, 1435-1440.

Estruch JJ, Carozzi NB, Desai N, Duck NB, Warren GW \& Koziel MG (1997) Transgenic plants: an emerging approach to pest control. Nature Biotechnology 15, 137-141.

Falco SC (1998) Chimeric genes and methods for increasing the lysine and threonine content of the seeds of plants. US Patent 5773691.

Falco SC, Guida T, Locke M, Mauvis J, Sanders C, Ward RT \& Webber PO (1995) Transgenic canola and soybean seeds with increased lysine. Bio/Technology 13, 577-582.

Fettig S \& Hess D (1999) Expression of a chimeric stilbene synthase gene in transgenic wheat lines. Transgenic Research 8, 179-189.

Flor HH (1971) Current status of the gene-for-gene concept. Annual Review of Phytopathology 9, 275-296.

Food and Agriculture Organization (2000) Fertilizer Requirements in 2015 and 2030. Rome: FAO.

Food and Agriculture Organization (2001) The State of Food Insecurity in the World. Rome: FAO.

Fraisier V, Gojon A, Tillard P \& Daniel-Vedele F (2000) Constitutive expression of a putative high-affinity nitrate transporter in Nicotiana plumbaginifolia: evidence for post-transcriptional regulation by a reduced nitrogen source. The Plant Journal 23, 489-496.

Fry WE \& Goodwin SB (1997) Re-emergence of potato and tomato late blight in the United States. Plant Disease 81, 1349-1357. 
Fu XD, Sudhakar D, Peng JR, Richards DE, Christou P \& Harberd NP (2001) Expression of Arabidopsis GAI in transgenic rice represses multiple gibberellin responses. Plant Cell 13, 1791-1802.

Fujimoto H, Itoh K, Yamamoto M, Kyozuka J \& Shimamoto K (1993) Insect resistant rice generated by introduction of a modified $\delta$-endotoxin gene of Bacillus thuringiensis. Bio/Technology 11, 1151-1155.

Gao A-G, Hakimi SM, Mittanck CA, Wu Y, Woerner BM, Stark DM, Shah DM, Liang JH \& Rommens CMT (2000) Fungal pathogen protection in potato by expression of a plant defensin peptide. Nature Biotechnology 18, 1307-1310.

Gatehouse AMR \& Gatehouse JR (1998) Identifying proteins with insecticidal activity: use of encoding genes to produce insectresistant transgenic crops. Pesticide Science 52, 165-175.

Gatehouse AMR, Shi Y, Powell KS, Brough C, Hilder VA, Hamilton WDO, Newell CA, Merryweather A, Boulter D \& Gatehouse JA (1993) Approaches to insect resistance using transgenic plants. Philosophical Transactions of the Royal Society of London 342B, 279-286.

Ghareyazie B, Alinia F, Menguito CA, Rubia LG, De Palma JM, Liwanag EA, Cohen MB, Khush GS \& Bennett J (1997) Enhanced resistance to two stem borers in an aromatic rice containing a synthetic CryIA(b) gene. Molecular Breeding 3, 401-414.

Goto F, Yoshihara T, Shigemoto N, Toki S \& Takaiwa F (1999) Iron fortification of rice seeds by the soybean ferritin gene. Nature Biotechnology 17, 282-286.

Graham RD, Welch RM \& Bouis HE (2001) Addressing micronutrient malnutrition through enhancing the nutritional quality of staple foods: principles, perspectives and knowledge gaps. Advances in Agronomy 70, 77-142.

Gressel J (2002) Transgenic herbicide-resistant crops - advantages, drawbacks and failsafes. In Plant Biotechnology and Transgenic Plants, pp. 597-633 [K-M Oksman-Caldentey and WH Barz, editors]. New York: Marcel Dekker.

Grichko VP \& Glick BR (2001a) Amelioration of flooding stress by ACC deaminase-containing plant growth-promoting bacteria. Plant Physiology and Biochemistry 39, 11-17.

Grichko VP \& Glick BR (2001b) Ethylene and flooding stress in plants. Plant Physiology and Biochemistry 39, 1-9.

Guo W, Qun SX, Xing DQ, Bolin L \& Yuxiang J (1998) Transgenic rice plants with parasponia haemoglobin gene and its expression. In Nitrogen Fixation with Non-Legumes. Proceedings of the Seventh International Symposium on Nitrogen Fixation with Non-Legumes, pp. 125-131 [KA Mallik, MS Mizza and JK Ladha, editors]. Dordrecht, The Netherlands: Kluwer Academic Publishing.

Hain R, Reif H-J, Krause E, Langebartels R, Kindl H, Vornam B, Wiese W, Schmeltzer E, Schreier PH, Stöker RH \& Stenzel K (1993) Disease resistance results from foreign phytoalexin expression in a novel plant. Nature 361, 153-156.

Harrison J, Brugiere N, Phillipson B, Ferrario-Mery S, Becker T, Limami A \& Hirel B (2000) Manipulating the pathway of ammonia assimilation through genetic engineering and breeding: consequences to plant physiology and plant development. Plant and Soil 221, 82-93.

Hasegawa PM, Bressan RA, Zhu JK \& Bohnert HJ (2000) Plant cellular and molecular responses to high salinity. Annual Review of Plant Physiology and Plant Molecular Biology 51, 12043-12048.

Hayes JE, Richardson AE \& Simpson RJ (1999) Phytase and acid phosphatase activities in extracts from roots of temperate pasture grass and legume seedlings. Australian Journal of Plant Physiology 26, 801-809.

Herrera-Estrella L \& Simpson J (1995) Genetically-engineered resistance to bacterial and fungal pathogens. World Journal of Microbiology and Biotechnology 11, 383-392.
Hilder VA \& Boulter D (1999) Genetic engineering of crop plants for insect resistance - a critical review. Crop Protection 18, 177-191.

Hill R \& Hillebrand H (2001) Plant concepts for mineral acquisition and allocation. Current Opinion in Biotechnology $\mathbf{1 2}$, 161-168.

Holmberg N \& Bulow L (1998) Improving stress tolerance in plants by gene transfer. Trends in Plant Science 3, 61-66.

Hossain M \& Singh VP (2000) Fertilizer use in Asian agriculture: implications for sustaining food security and the environment. Nutrient Cycling in Agroecosystems 52, 213-223.

Huang C, Barker SJ, Langridge P, Smith FW \& Graham RD (2000) Zinc deficiency up-regulates expression of high-affinity phosphate transporter genes in both phosphate-sufficient and -deficient barley roots. Plant Physiology 124, 415-422.

Huang J, Pray C \& Rozelle S (2002a) Enhancing the crops to feed the poor. Nature 418, 678-683.

Huang J, Rozelle SD, Pray CE \& Wang Q (2002b) Plant biotechnology in China. Science 295, 674-677.

Huang N-C, Liu K-H, Lo H-J \& Tsay Y-F (1999) Cloning and functional characterization of an Arabidopsis nitrate transporter gene that encodes a constitutive component of low-affinity uptake. Plant Cell 11, 1381-1392.

Hunter KJ (2001) Method for increasing vitamin C content of plants. Patent application WO 01/07634.

Hwang CF, Bhakta AV, Truesdell GM, Pudlo WM \& Williamson VM (2000) Evidence for a role of the $\mathrm{N}$ terminus and leucinerich repeat region of the Mi gene product in regulation of localized cell death. Plant Cell 12, 1319-1329.

Ishimaru K, Okhawa Y, Ishige T, Tobias DJ \& Ohsugi R (1998) Elevated pyruvate orthophosphate dikinase (PPDK) activity alters carbon metabolism in $\mathrm{C}_{3}$ transgenic potatoes with a $\mathrm{C}_{4}$ maize PPDK gene. Physiologia Plantarum 103, 340-346.

Itoh H, Ueguchi-Tanaka M, Sentoku N, Kitano H, Matsuoka M \& Kobayashi M (2001) Cloning and functional analysis of two gibberellin $3 \beta$-hydroxylase genes that are differently expressed during the growth of rice. Proceedings of the National Academy of Sciences USA 98, 8909-8914.

James C (2002) Global Status of Commercialized Transgenic Crops: 2002. ISAAA Briefs no. 27. Ithaca, NY: ISAAA.

Jeon J-S, Lee S, Jung K-H, Yang W-S, Yi G-H, Oh B-G \& An G (2000) Production of transgenic rice plants showing reduced heading date and plant height by ectopic expression of rice MADS-box genes. Molecular Breeding 6, 581-592.

Joel DM, Kleifeld Y, Losner-Goshen D, Herzlinger G \& Gressel J (1995) Transgenic crops against parasites. Nature 374, 220-221.

John P (1997) Ethylene biosynthesis: the role of 1-aminocyclopropane-1-carboxylate (ACC) oxidase, and its possible evolutionary origin. Physiologia Plantarum 100, 583-592.

Jongedijk E, Tigelaar H, Van Roekel JSC, Bres-Vloemans SA, Dekker I, Van den Elzen PJM, Cornelissen BJC \& Melchers LS (1995) Synergistic activity of chitinases and $\beta$-1,3-glucanases enhances fungal resistance in transgenic tomato plants. Euphytica 85, 173-180.

Jung C, Cai D \& Kleine M (1998) Engineering nematode resistance in crop species. Trends in Plant Science 3, 266-271.

Kanampiu FK, Ransom JK \& Gressel J (2001) Imazapyr seed dressings for Striga control on acetolactate synthase target-site resistant maize. Crop Protection 20, 885-895.

Kanampiu FK, Ranson JK, Gressel J, Jewell D, Friesen D, Grimanelli D \& Hoisington D (2002) Appropriateness of biotechnology to African agriculture: Striga and maize as paradigms. Plant Cell Tissue and Organ Culture 69, 105-110.

Kang H-G \& An G (1997) Isolation and characterization of a rice MADS box gene belonging to the $A G L 2$ gene family. Molecules and Cells 7, 45-51. 
Kang H-G, Jang S, Chung J-E, Cho Y-G \& An G (1997) Characterization of two rice MADS box genes that control flowering time. Molecules and Cells 7, 559-566.

Kesarwani M, Azam M, Natarajan K, Mehta A \& Datta A (2000) Oxalate decarboxylase from Collybia velutipes. Molecular cloning and its overexpression to confer resistance to fungal infection in transgenic tobacco and tomato. Journal of Biological Chemistry 275, 7230-7238.

Khanna HK \& Raina SK (2002) Elite indica transgenic plants expressing modified Cry1Ac endotoxin of Bacillus thuringiensis show enhanced resistance to yellow stem borer (Scirpophaga incertulas). Transgenic Research 11, 411-423.

Khush GS, Bacalangco E \& Ogawa T (1990) A new gene for resistance to bacterial blight from $O$ longistaminata. Rice Genetics Newsletter 7, 121-122.

Kloti A, Futterer J, Terada R, Bieri S, Wunn J, Burkhardt PK, Chen G, Hohn TH, Biswas GC \& Potrykus I (1996) Towards genetically engineered resistance to tungro virus. In Rice Genetics III, Proceedings of the Third International Rice Genetics Symposium, pp. 763-767 [GS Khush, editor]. Manila, The Philippines: IRRI, Los Banos.

Koyama H, Kawamura A, Kihara T, Hara T, Takita E \& Shibata D (2000) Overexpression of mitrochondrial citrate synthase in Arabidopsis thaliana improved growth on phosphorus-limited soil. Plant and Cell Physiology 9, 1030-1037.

Ku MSB, Agarie S, Nomura M, Fukayama H, Tsuchida H, Ono K, Hirose S, Toki S, Miyao M \& Matsuoka M (1999) High level expression of maize phosphoenol pyruvate carboxylase in transgenic rice plants. Nature Biotechnology 17, 76-80.

Kuc J (1995) Phytoallexins: stress metabolism and disease resistance in plants. Annual Review of Phytopathology 33, 275-297.

Kwon C, Chung W \& Paek K (1997) Ribozyme mediated targeting of cucumber mosaic virus RNA 1 and 2 in transgenic tobacco plants. Molecules and Cells 7, 326-334.

Lamb C \& Dixon RA (1997) The oxidative burst in plant disease resistance. Annual Review of Plant Physiology and Plant Molecular Biology 48, 251-275.

Lawrence PK \& Koundal KR (2002) Plant protease inhibitors in control of phytophagous insects. Electronic Journal of Biotechnology 5, 1-9.

Leckband G \& Lörz H (1998) Transformation and expression of a stilbene synthase gene of Vitis vinifera L. in barley and wheat for increased fungal resistance. Theoretical and Applied Genetics 96, 1004-1012.

Lee OS, Lee B, Park N, Koo JC, Kim YH, Prasad T, Karigar C, Chun HJ, Jeong BR, Kim DH, Nam J, Yun JG, Kwak SS, Cho MJ \& Yun DJ (2003) Pn-AMPs, the hevein-like proteins from Pharbitis nil, confer disease resistance against phytopathogenic fungi in tomato, Lycopersicon esculentum. Phytochemistry 62, 1073-1079.

Lentini Z, Calvert L, Tabares E, Lozano I, Ramirez BC \& Roca W (1996) Genetic transformation of rice with viral genes for novel resistance to rice hoja blanca virus. In Rice Genetics III, Proceedings of the Third International Rice Genetics Symposium, pp. 780-783 [GS Khush, editor]. Manila, The Philippines: IRRI, Los Banos.

Li Q, Lawrence CB, Xing H-Y, Babbitt RA, Bass WT, Maiti IB \& Everett NP (2001) Enhanced disease resistance conferred by expression of an antimicrobial magainin analog in transgenic tobacco. Planta 212, 635-639.

Lightfoot DA, Bernhardt K, Ameziane R, Bates R \& Long LM (1998) Expression of the Escherichia coli glutamate dehydrogenase gene in Nicotiana tabacum and Zea mays increases yield. US patent 5998700 .

Lipton M (1999) Reviving Global Poverty Reduction: What Role for Genetically Modified Crops? 1999 Sir John Crawford Memorial Lecture. CGIAR International Centers Week, October 28, 1999. Washington, DC: CGIAR.
Liu D, Raghothama KG, Hasegawa PM \& Bressan R (1994) Osmotin overexpression in potato delays development of disease symptoms. Proceedings of the National Academy of Sciences USA 91, 1888-1892.

Llewellyn DJ \& Higgins TJV (2002) Transgenic crop plants with increased tolerance to insect pests. In Plant Biotechnology and Transgenic Plants, pp. 571-595 [K-M Oksman-Caldentey and WH Barz, editors]. New York: Marcel Dekker.

Loneragen JP (1997) Plant nutrition in the 20th and perspectives for the 21st century. Plant and Soil 196, 163-174.

Lopez-Bucio J, Martınez de la Vega O, Guevara-Garcıa A \& Herrera-Estrella L (2000a) Enhanced phosphorus uptake in transgenic tobacco plants that overproduce citrate. Nature Biotechnology 18, 450-453.

Lopez-Bucio J, Nieto-Jacobo MF, Ramırez-Rodriguez V \& Herrera-Estrella L (2000b) Organic acid metabolism in plants: from adaptive physiology to transgenic varieties for cultivation in extreme soils. Plant Science 160, 1-13.

Lucca P, Hurrell R \& Potrykus I (2001a) Genetic engineering approaches to improve the bioavailability and the level of iron in rice grains. Theoretical and Applied Genetics 102, 392-397.

Lucca P, Ye X \& Potrykus I (2001b) Effective selection and regeneration of transgenic rice plants with mannose as selective agent. Molecular Breeding 7, 43-49.

McKibbin RS, Halford NG \& Francis D (1998) Expression of fission yeast $c d c 25$ alters the frequency of lateral root formation in transgenic tobacco. Plant Molecular Biology 36, 601-612.

Mandel MA \& Yanofsky MF (1995) A gene triggering flower formation in Arabidopsis. Nature 377, 522-524.

Marshner H (1995) Mineral Nutrition of Higher Plants. London: Academic Press.

Matsuoka M, Nomura M, Agarie S, Tokutomi M \& Ku MSB (1998) Evolution of $C_{4}$ photosynthetic genes and overexpression of maize $\mathrm{C}_{4}$ genes in rice. Journal of Plant Research 111, 333-337.

Mitsukawa N, Okumura S, Shirano Y, Sato S, Kato T, Harashima S \& Shibata D (1997) Overexpression of an Arabidopsis thaliana high affinity phosphate transporter gene in tobacco cultured cells enhances cell growth under phosphate-limited conditions. Proceedings of the National Academy of Sciences USA 94, 7078-7120.

Miyagawa Y, Tamoi M \& Shigeoka S (2001) Overexpression of a cyanobacterial fructose-1,6-sedoheptulose-1,7-bisphosphatase in tobacco enhances photosynthesis and growth. Nature Biotechnology 19, 965-969.

Mizukami Y \& Ma H (1997) Determination of Arabidopsis floral meristem identity by AGAMOUS. Plant Cell 9, 393-408.

Moon Y, Song S, Choi K \& Lee J (1997) Expression of a cDNA encoding Phytolacca insularis antiviral protein confers virus resistance on transgenic potato plants. Molecules and Cells 7 , $807-815$

Mourgues F, Brisset M-N \& Chevreau E (1998) Strategies to improve plant resistance to bacterial diseases through genetic engineering. Trends in Biotechnology 16, 203-210.

Nayak P, Basu D, Das S, Basu A, Ghosh D, Ramakrishna NA, Ghosh M \& Sen SK (1997) Transgenic elite indica rice plants expressing CryIAc $\delta$-endotoxin of Bacillus thuringiensis are resistant against yellow stem borer (Scirpophaga incertulas). Proceedings of the National Academy of Sciences USA 94, 2111-2116.

Ogawa T, Hori T \& Ishida I (1996) Virus-induced cell death in plants expressing the mammalian $2^{\prime}, 5^{\prime}$ oligoadenylate system. Nature Biotechnology 14, 1566-1569.

Osusky M, Zhou G, Osuska L, Hancock RE, Kay WW \& Misra S (2000) Transgenic plants expressing cationic peptide chimeras exhibit broad-spectrum resistance to phytopathogens. Nature Biotechnology 18, 1162-1166. 
Pachico D, Hertford R \& de Janvry A (2000) Assessing the impact of agricultural research on poverty alleviation. Food Policy 25, 379-388.

Paul M, Pellny T \& Goddijn O (2001) Enhancing photosynthesis with sugar signals. Trends in Plant Science 6, 197-200.

Peferoen M (1997) Progress and prospects for field use of $B t$ genes in crops. Trends in Biotechnology 15, 173-177.

Peng JR, Richards DE, Hartley NM, Murphy GP, Devos KM, Flintham JE, Beales J, Fish LJ, Worland AJ, Pelica F, Sudhakar D, Christou P, Snape JW, Gale MD \& Harberd NP (1999) 'Green revolution' genes encode mutant gibberellin response modulators. Nature 400, 256-261.

Persley G (2000) Agricultural biotechnology and the poor: Promethean science. In Agricultural Biotechnology and the Poor: Proceedings of an International Conference, Washington, DC, 21-22 October 1999, pp. 1-36 [GJ Persley and MM Lantin, editors]. Washington, DC: Consultative Group on International Agricultural Research.

Pinstrup-Andersen P, Pandra-Lorch R \& Rosegrant MW (1999) World Food Prospects: Critical Issues for the Early TwentyFirst Century. Food Policy Report. Washington, DC: International Food Policy Research Institute.

Pinto YM, Kok RA \& Baulcombe DC (1999) Resistance to rice yellow mottle virus (RYMV) in cultivated African rice varieties containing RYMV transgene. Nature Biotechnology 17, 702-707.

Potrykus I (2001) Golden rice and beyond. Plant Physiology 125, $1157-1161$.

Powell ALT, Van Kan J, ten Have A, Visser J, Greve LC, Bennett AB \& Labavitch JM (2000) Transgenic expression of pear PGIP in tomato limits fungal colonization. Molecular Plant-Microbe Interactions 13, 942-950.

Pray C, Huang J, Hu R \& Rozelle S (2002) Five years of Bt cotton in China - the benefits continue. The Plant Journal 31, 423-430.

Punja ZK (2001) Genetic engineering of plants to enhance resistance to fungal pathogens - a review of progress and future prospects. Canadian Journal of Plant Pathology 23, 216-235.

Regierer B, Fernie AR, Springer F, Perez-Melis A, Leissel A, Koehl K, Willmitzer L, Geigenberger P \& Kossmann J (2002) Starch content and yield increase as a result of altering adenylate pools in transgenic plants. Nature Biotechnology 12, $1256-1260$.

Romer S, Fraser PD, Kiano JW, Shipton CA, Misawa N, Schuch W \& Bramley PM (2000) Elevation of the provitamin A content of transgenic tomato plants. Nature Biotechnology 18, 666-669.

Rosche E, Blackmore D, Tegeder M, Richardson T, Schroeder H, Higgins TJV, Frommer WB, Offler CE \& Patrick JW (2002) Seed-specific overexpression of the potato sucrose transporter increases sucrose uptake and growth rates of developing pea cotyledons. The Plant Journal 30, 165-175.

Rosegrant MW, Paisner MS, Meijer S \& Witcover J (2001) 2020 Global Food Outlook: Trends, Alternatives and Choices. A 2020 Vision for Food, Agriculture and the Environment Initiative. Washington, DC: IFPRI.

Royal Society of London, US National Academy of Sciences, Brazilian Academy of Sciences, Chinese Academy of Sciences, Indian National Academy of Sciences, Mexican Academy of Sciences \& Third World Academy of Sciences (2000) Transgenic Plants and World Agriculture. Washington, DC: National Academy Press.

Sakamoto A \& Murata N (2000) Genetic engineering of glycinebetaine synthesis in plants: current status and implications for enhancement of stress tolerance. Journal of Experimental Botany 51, 81-88.
Sakamoto A \& Murata N (2001) The use of bacterial choline oxidase, a glycine betaine-synthesizing enzyme, to create stressresistant transgenic plants. Plant Physiology 125, 180-188.

Sakamoto A, Murata A \& Murata N (1998) Metabolic engineering of rice leading to biosynthesis of glycinebetaine and tolerance to salt and cold. Plant Molecular Biology 38, 1011-1019.

Sakamoto T, Kobayashi M, Itoh H, Tagiri A, Kayano T, Tanaka H, Iwahori S \& Matsuoka M (2001) Expression of a gibberellin 2-oxidase gene around the shoot apex is related to phase transition in rice. Plant Physiology 125, 1508-1516.

Salmeron JM \& Vernooij B (1998) Transgenic approaches to microbial disease resistance in crop plants. Current Opinion in Plant Biology 1, 347-352.

Schillberg S, Zimmermann S, Zhang M-Y \& Fischer R (2001) Antibody-based resistance to plant pathogens. Transgenic Research 10, 1-12.

Scholthof K-BG (2003) One foot in the furrow: linkages between agriculture, plant pathology and public health. Annual Review of Public Health 24, 153-174.

Schuler TH, Poppy GM, Kerry BR \& Denholm I (1998) Insect resistant transgenic plants. Trends in Biotechnology 16, 168-175.

Serraj R \& Sinclair TR (2002) Osmolyte accumulation: can it really help increase crop yield under drought conditions? Plant Cell and Environment 25, 333-341.

Shintani D \& DellaPenna D (1998) Elevating the vitamin E content of plants through metabolic engineering. Science $\mathbf{2 8 2}$, 2098-2100.

Sindhu AS, Sheng Z \& Murai N (1997) The pea seed storage protein legumin was synthesized, processed and accumulated stably in transgenic rice endosperm. Plant Science 130, 189-196.

Sivamani E, Huet H, Shen P, Ong CA, de Kochko A, Fauquet C \& Beachy RN (1999) Rice plant (Oryza sativa L.) containing rice tungro spherical virus (RTSV) coat protein transgenes are resistant to virus infection. Molecular Breeding 5, 177-185.

Smidansky ED, Clancy M, Meyer FD, Lanning SP, Blake NK, Talbert LE \& Giroux MJ (2002) Enhanced ADP-glucose pyrophosphorylase activity in wheat endosperm increases seed yield. Proceedings of the National Academy of Sciences USA 99, 1724-1729.

Smidansky ED, Martin JM, Hannah LC, Fischer AM \& Giroux MJ (2003) Seed yield and plant biomass increases in rice are conferred by deregulation of endosperm ADP-glucose pyrophosphorylase. Planta 216, 656-664.

Smith LC, El Obeid AE \& Jensen HH (2000) The geography and causes of food insecurity in developing countries. Agricultural Economics 22, 199-215.

Song WY, Wang G, Chen L, Kim H, Pi LY, Holsten T, Gardner J, Wang B, Zha W, Zhu L, Fauquet C \& Ronald P (1995) A receptor kinase-like protein encoded by the rice disease resistance gene, Xa-21. Science 270, 1804-1806.

Sonnewald U, Hajirezaei MR, Kossmann J, Heyer A, Trethewey RN \& Willmitzer L (1997) Increased potato tuber size resulting from apoplastic expression of a yeast invertase. Nature Biotechnology 15, 794-797.

Stanilaus MA \& Cheng C-L (2002) Genetically engineered selfdestruction: an alternative to herbicides for cover crop systems. Weed Science 50, 794-801.

Stark DM, Timmerman KP, Barry GF, Preiss J \& Kishore GM (1992) Regulation of the amount of starch in plant tissue by ADP glucose pyrophosphorylase. Science 258, 287-292.

Stark-Lorenzen P, Nelke B, Hänbler G, Mühlbach HP \& Thomzik JE (1997) Transfer of a grapevine stillbene synthase gene to rice (Oryza sativa L.). Plant Cell Reports 16, 668-673.

Stearns JC \& Glick BR (2003) Transgenic plants with altered ethylene biosynthesis or perception. Biotechnology Advances 21, 193-210. 
Sticher L, Mauch-Mani B \& Metraux JP (1997) Systemic acquired resistance. Annual Review of Phytopathology 35, 235-270.

Stitt M (1999) Nitrate regulation of metabolism and growth. Current Opinion in Plant Biology 2, 178-186.

Stoger E, Parker M, Christou P \& Casey R (2001) Pea legumin overexpressed in wheat endosperm assembles into an ordered paracrystalline matrix. Plant Physiology 125, 1732-1742.

Stuiver MH \& Custers JHHV (2001) Engineering disease resistant plants. Nature 411, 865-868.

Sung S-K, Yu G-H \& An G (1999) Characterization of $M d M A D S 2$, a member of the SQUAMOSA subfamily of genes, in apple. Plant Physiology 120,969-978.

Szymanski DB, Lloyd AM \& Marks MD (2000) Progress in the molecular genetic analysis of trichome initiation and morphogenesis in Arabidopsis. Trends in Plant Science 5, 214-219.

Tang KX, Sun XF, Hu QN, Wu AZ, Lin CH, Lin HJ, Twyman RM, Christou P \& Feng TY (2001) Transgenic rice plants expressing the ferredoxin-like protein (API) from sweet pepper show enhanced resistance to Xanthomonas oryzae pv. oryzae. Plant Science 160, 1035-1042.

Tavladoraki P, Benvenuto E, Trinca S, De Martinis D, Cattaneo A \& Galeffi P (1993) Transgenic plants expressing a functional single-chain $\mathrm{Fv}$ antibody are specifically protected from virus attack. Nature 366, 469-472.

Thiele A, Herold M, Lenk I, Quail H \& Gatz C (1999) Heterologous expression of Arabidopsis phytochrome B in transgenic potato influences photosynthetic performance and tuber development. Plant Physiology 120, 73-81.

Thomzik JE, Stenzel K, Stöcker R, Schreier PH, Hain R \& Stahl DJ (1997) Synthesis of a grapevine phytoalexin in transgenic tomatoes (Lycopersicon esculentum Mill.) conditions resistance against Phytophthora infestans. Physiological and Molecular Plant Pathology 51, 265-278.

Tjaden J, Mohlmann T, Kampfenkel K, Henrichs G \& Neuhaus HE (1998) Altered plastidic ATP/ADP-transporter activity influences potato (Solanum tuberosum L.) tuber morphology, yield and composition of tuber starch. The Plant Journal 16, 531-540.

Toenniessen GH, O'Toole JC \& DeVries J (2003) Advances in plant biotechnology and its adoption in developing countries. Current Opinion in Plant Biology 6, 191-198.

Traxler GS, Godoy-Avila S, Falck-Zepeda J \& Espinoza-Arellano J (2003) Transgenic cotton in Mexico: a case study of the comarca lagunera. In Economic and Environmental Impacts of Agbiotech: A Global Perspective, pp.183-203 [N Kalaitzandonakes, editor]. New York: Kluwer-Plenum Academic Publishers.

Trethewey RN, Geigenberger P, Riedel K, Hajirezaei MR, Sonnewald U, Stitt M, Riesmeier JW \& Willmitzer L (1998) Combined expression of glucokinase and invertase in potato tubers leads to a dramatic reduction in starch accumulation and a stimulation of glycolysis. The Plant Journal 15, $109-118$

Tu J, Ona I, Zhang Q, Mew TW, Khush GS \& Datta SK (1998) Transgenic rice variety 'IR72' with $\mathrm{Xa21}$ is resistant to bacterial blight. Theoretical and Applied Genetics 97, 31-36.

Tu J, Zhang G, Datta K, Xu C, He Y, Zhang Q, Khush GS \& Datta SK (2000) Field performance of transgenic elite commercial hybrid rice expressing Bacillus thuringiensis $\delta$-endotoxin. Nature Biotechnology 18, 1101-1104.

Tumer N, Hwang D \& Bonness M (1997) C-terminal deletion mutant of pokeweed antiviral protein inhibits viral infection but does not depurinate host ribosomes. Proceedings of the National Academy of Sciences USA 94, 3866-3871.

Urwin PE, Lilley CJ, McPherson MJ \& Atkinson HJ (1997) Resistance to both cyst and root-knot nematodes conferred by transgenic Arabidopsis expressing a modified plant cystatin. The Plant Journal 12, 455-461.
Urwin PE, Troth KM, Zubko EI \& Atkinson HJ (2001) Effective transgenic resistance to Globodera pallida in potato field trials. Molecular Breeding 8, 95-101.

Vain P, Worland B, Clarke MC, Richard G, Beavis M, Liu H, Kohli A, Leech M, Snape J, Christou P \& Atkinson HJ (1998) Expression of an engineered cysteine proteinase inhibitor (Oryzacystatin-I Delta D86) for nematode resistance in transgenic rice plants. Theoretical and Applied Genetics 96, 266-271.

Van den Elzen PJM, Jongedijk E, Melchers LS \& Cornelissen BJC (1993) Virus and fungal resistance: from laboratory to field. Philosophical Transactions of the Royal Society of London 342B, 271-278.

Van Frankenhuyzen K \& Nystrom C (2002) The Bacillus thuringiensis toxin specificity database. www.glfc.cfs.nrcan. gc.ca/bacillus

Van Wijk J (2002) Food insecurity: prevalence, causes and the potential of transgenic 'Golden Rice'. Phytochemistry Reviews 1, 141-151.

Wallace JC, Galili G, Kawata EE, Cuellar RE, Shotwell MA \& Larkins BA (1988) Aggregation of lysine-containing zeins into protein bodies in Xenopus oocytes. Science 240, 662-664.

Wang GL, Song WY, Ruan DL, Sideris S \& Ronald PC (1996) The cloned gene, $X a-21$, confers resistance to multiple Xanthomonas oryzae pv. oryzae isolates in transgenic plants. Molecular Plant-Microbe Interactions 9, 850-855.

Wang Y, Nowak G, Culley D, Hadwiger LA \& Fristensky B (1999) Constitutive expression of a pea defense gene DRR206 confers resistance to blackleg (Leptosphaeria maculans) disease in transgenic canola (Brassica napus). Molecular Plant-Microbe Interactions 12, 410-418.

Watanabe Y, Ogawa T, Takahashi H, Ishida I, Takeuchi Y, Yamamoto M \& Okada Y (1995) Resistance against multiple plant viruses in plants mediated by a double stranded-RNA specific ribonuclease. FEBS Letters 372, 165-168.

Whitney SM \& Andrews TJ (2001) Plastome-encoded bacterial ribulose-1,5-bisphosphate carboxylase/oxygenase (Rubisco) supports photosynthesis and growth of tobacco. Proceedings of the National Academy of Sciences USA 98, 14738-14743.

World Bank (2000) Attacking Poverty. World Development Report 2000/2001. Washington, DC: The World Bank.

World Health Organization (2001) Combating vitamin A deficiency. www.who.int/nut/vad.htm

Wu C, Fan Y, Zhang C, Oliva N \& Datta SK (1997) Transgenic fertile japonica rice plants expressing a modified $\operatorname{Cry} I A(b)$ gene resistant to yellow stem borer. Plant Cell Reports 17, 129-132.

Wunn J, Kloti A, Burkhardt PK, Ghosh Biswas GC, Launis K, Iglesias VA \& Potrykus I (1996) Transgenic indica rice breeding line IR-58 expressing a synthetic Cry IA (b) gene from Bacillus thuringiensis provides effective insect pest control. Bio/Technology 14, 171-176.

Xu DP, Duan XL, Wang BY, Hong BM, Ho THD \& Wu R (1996) Expression of a late embryogenesis abundant protein gene, $H V A 1$, from barley confers tolerance to water deficit and salt stress in transgenic rice. Plant Physiology 110, 249-257.

Yamamuro C, Ihara Y, Wu X, Noguchi T, Fujioka S, Takatsuto S, Ashikari M, Kitano H \& Matsuoka M (2000) Loss of function of a rice brassinosteroid insensitive 1 homolog prevents internode elongation and bending of the lamina joint. Plant Cell 12, 1591-1606.

Yancey PH, Clark ME, Hand SC, Bowlus RD \& Somero GN (1982) Living with water stress: evolution of osmolyte systems. Science 217, 1214-1222.

Ye GY, Shu QY, Yao HW, Cui HR, Cheng XY, Hu C, Xia YW, Gao MW \& Altosaar I (2001a) Field evaluation of resistance of transgenic rice containing a synthetic $c r y l A b$ gene from Bacillus thuringiensis Berliner to two stem borers. Journal of Economic Entomology 94, 271-276. 
Ye GY, Tu J, Hu C, Datta K \& Datta SK (2001b) Transgenic IR72 with fused Bt gene crylAb/crylAc from Bacillus thuringiensis is resistant against four Lepidopteran species under field conditions. Plant Biotechnology 18, 125-133.

Ye XD, Al-Babili S, Kloti A, Zhang J, Lucca P, Beyer P \& Potrykus I (2000) Engineering the provitamin A (beta-carotene) biosynthetic pathway into (carotenoid-free) rice endosperm. Science 287, 303-305.

Yeo ET, Kwon HB, Han SE, Lee JT, Ryu JC \& Byun MO (2000) Genetic engineering of drought-resistant potato plants by introduction of the trehalose-6-phosphate synthase (TPS1) gene from Saccharomyces cerevisiae. Molecules and Cells 10, 263-268.

Zhang HX \& Blumwald E (2001) Transgenic salt-tolerant tomato plants accumulate salt in foliage but not in fruit. Nature Biotechnology 19, 765-768.

Zhang HX, Hodson JN, Williams JP \& Blumwald E (2001) Engineering salt-tolerant Brassica plants: characterization of yield and seed oil quality in transgenic plants with increased vacuolar sodium accumulation. Proceedings of the National Academy of Sciences USA 98, 12832-12836.

Zhang J, Kueva NY, Wang Z, Wu R, Ho T-H \& Nguyen HT (2000) Genetic engineering for abiotic stress tolerance in crop plants. In Vitro Cellular and Developmental Biology - Plant 36 , 108-114.

Zhang S, Song WY, Chen L, Ruan D, Taylor N, Ronald P, Beachy R \& Fauquet C (1998) Transgenic elite indica rice varieties, resistant to Xanthomonas pv. oryzae. Molecular Breeding 4, 551-558.

Zhu B, Chen THH \& Li PH (1996) Analysis of late-blight disease resistance and freezing tolerance in transgenic potato plants expressing sense and antisense genes for an osmotin-like protein. Planta 198, 70-77.

Zhu JK (2001) Cell signaling under salt, water and cold stress. Current Opinion in Plant Biology 4, 401-406.

Zhu Q, Maher EA, Masoud S, Dixon RA \& Lamb CJ (1994) Enhanced protection against fungal attack by constitutive coexpression of chitinase and glucanase genes in transgenic tobacco. Bio/Technology 12, 807-812. 